\title{
Taxonomic study on coprophilous species of Coprinopsis (Psathyrellaceae, Agaricales) from Punjab, India
}

\author{
Amandeep $\mathrm{K}^{1^{*}}$, Atri $\mathrm{NS}^{2}$ and Munruchi $\mathrm{K}^{2}$ \\ ${ }^{1}$ Desh Bhagat College of Education, Bardwal-Dhuri-148024, Punjab, India. \\ ${ }^{2}$ Department of Botany, Punjabi University, Patiala-147002, Punjab, India.
}

Amandeep K, Atri NS, Munruchi K 2014 - Taxonomic study on coprophilous species of Coprinopsis (Psathyrellaceae, Agaricales) from Punjab, India. Mycosphere 5(1), 1-25, Doi 10.5943/mycosphere/5/1/1

\begin{abstract}
The diversity of Coprinopsis species has been studied from the coprophilous habitats throughout the Punjab state from 2007 to 2011. Twelve taxa namely $C$. cinerea, C. cothurnata var. equsterca, C. foetidella, C. lagopides var. lagopides, C. lagopus, C. macrocephala, C. nivea, C. pseudonivea, C. radiata, C. radiata var. macrocarpa, C. scobicola and $C$. vermiculifera are reported. Out of these, C. radiata var. macrocarpa and C. cothurnata var. equsterca are proposed as new varieties and Coprinus foetidellus is transferred to Coprinopsis foetidella. Two species, viz. Coprinopsis pseudonivea and C. vermiculifera are first time records from India. In this paper, all these taxa are described, illustrated, and compared with similar species. A dichotomous key to aid in their identification is also given.
\end{abstract}

Key words - Basidiomycota - deliquescent - diversity - pseudoparaphyses - systematics

\section{Introduction}

The coprinoid species which possess hyphal pileus cuticle, abundant powdery to floccose veil covering the whole pileus and coprophilous, terrestrial or lignicolous habitat represent the genus Coprinopsis (Readhead et al. 2001). Myco Bank (www.mycobank.org) documents 144 records and Wikipedia (en.wikipedia.org) shows a list of 32 species up to 20 December, 2013. According to Kirk et al. (2008), 200 species of Coprinopsis are known so far the world over. As many as 27 species of this genus are known from India and 15 species from Punjab (Rea 1922, Mahju 1933, Ginai 1936, Pathak \& Ghosh 1962, Vasudeva 1962, Kaul \& Kachroo 1974; Watling \& Gregory 1980; Natarajan \& Raaman 1983, 1984; Purkayastha \& Chandra 1985, Abraham 1991, Bhavani Devi 1995, Patil et al. 1995, Saini \& Atri 1995, Atri \& Kaur 2004).

In the present study, 23 collections have been worked out and identified. These belong to 12 species namely $C$. cinerea (Schaeff.) Redhead, Vilgalys and Moncalvo, C. cothurnata (Godey) Redhead, Vilgalys and Moncalvo var. equsterca Atri, A. Kaur \& M. Kaur var. nov., C. foetidella (P. D. Orton) Atri, A. Kaur \& M. Kaur comb. nov., C. lagopides var. lagopides (P. Karst.) Redhead, Vilgalys and Moncalvo, C. lagopus (Fr.) Redhead, Vilgalys and Moncalvo, $C$. macrocephala (Berk.) Redhead, Vilgalys and Moncalvo, C. nivea (Pers.) Redhead, Vilgalys and Moncalvo, C. pseudonivea (Bender and Uljé) Redhead, Vilgalys and Moncalvo, $C$. radiata (Bolton: Fr.) Redhead, Vilgalys and Moncalvo, C. radiata (Bolton: Fr.) Redhead, Vilgalys and 
Moncalvo var. macrocarpa Atri, A. Kaur \& M. Kaur var. nov., C. scobicola (P.D. Orton) Redhead, Vilgalys and Moncalvo and C. vermiculifera (Joss.: Dennis) Redhead, Vilgalys and Moncalvo of this genus. Out of these, two new varieties viz. $C$. radiata var. macrocarpa var. nov. and $C$. cothurnata var. equsterca var. nov. have been proposed. One new combination viz. $C$. foetidella comb. nov. has been made. Two species, namely $C$. pseudonivea and $C$. vermiculifera are first time records from India. One species, namely $C$. macrocephala is the first time record from North India. Two species, namely $C$. scobicola and $C$. lagopides var. lagopides are recorded as new from Punjab and four species, namely $C$. cinerea, $C$. lagopus, $C$. nivea and $C$. radiata are re-recorded from the state.

\section{Materials and Methods}

The macroscopic features of the collected materials were documented on the 'Field key to Mushroom collector' (Atri \& Saini 2000, Atri et al. 2005). The color terminology used for description is that of Kornerup \& Wanscher (1978). The microscopic characters were observed by cutting free hand sections after reviving a part of the dried specimen in $10 \% \mathrm{KOH}$. The drawings were made with the aid of Camera Lucida under oil immersion lens. Basidium length excludes the length of sterigmata. The spore quotient $(\mathrm{Q}=\mathrm{L} / \mathrm{W})$ was calculated considering the mean value of length divided by the width of 30 basidiospores. The specimens have been deposited in the Herbarium of Punjabi University (PUN), Patiala, India. Herbarium acronym follows Holmgren \& Keuken (1974).

\section{Key to the investigated coprophilous species of Coprinopsis}



1' Pileal veil composed of cellular elements.....................................................

2 Veil hyphae branched, thick-walled; carpophores very small, 2.8-3 cm in height; pileus 1.4-1.7

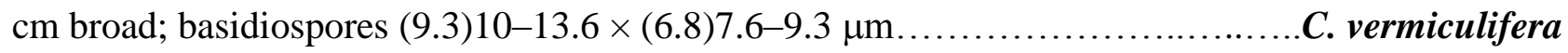
$\mathbf{2}^{\prime}$ Veil hyphae unbranched, thin-walled; carpophores small to large, 3-16 cm in height.

3 Veil made up of elongated cylindrical hyphae, without ellipsoidal or subglobose elements; basidia 2-spored, very rarely 4-spored; cheilocystidia and pleurocystidia with irregular granular contents; growing solitary on sheep dung.

C. scobicola $3^{\prime}$ Veil made up of ellipsoidal or subglobose hyphal elements; basidia 4-spored; cheilocystidia and pleurocystidia slightly granular to hyaline; growing scattered or in group .........................4

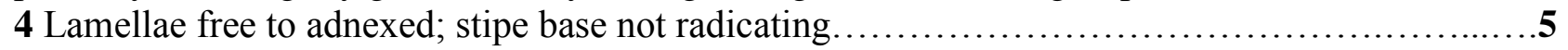

$\mathbf{4}^{\prime}$ Lamellae free; stipe base radicating into a pseudorrhiza..................................6

5 Pileus campanulate to applanate, finally plano-concave with revolute margin, umbonate; stipe $0.2-0.35 \mathrm{~cm}$ broad; lamellae subdistant, moderately broad; basidiospores 10-13.6 $\times 6.8-9.3$

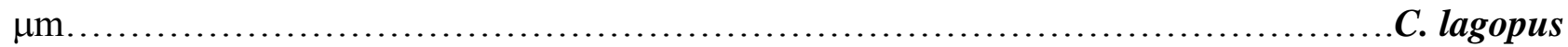
5' Pileus conical to campanulate, exumbonate; stipe $0.5-0.6 \mathrm{~cm}$ broad; lamellae crowded, narrow; basidiospores $7-8.5 \times 5-6.4 \mu \mathrm{m} \ldots \ldots \ldots \ldots \ldots \ldots \ldots \ldots \ldots \ldots \ldots \ldots \ldots \ldots \ldots \ldots \ldots$ lagopides var. lagopides 6 Pseudorrhiza very small, up to up to $1.3 \mathrm{~cm}$ long; average spore breadth more than 8.5 $\mu \mathrm{m}$. C. macrocephala

6' Pseudorrhiza comparatively elongated, $1.7-7 \mathrm{~cm}$ long; average spore breadth less than $8.5 \mu \mathrm{m} . . .7$ 7 Cheilocystidia globose to subglobose; basidiospores $8.5-12 \mu \mu \mathrm{m}$

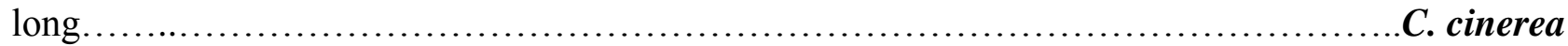

$\mathbf{7}^{\prime}$ Cheilocystidia ellipsoidal to clavate; basidiospores more than $11 \mu \mathrm{m}$ long......................8 8 Carpophores small, 3.3-4.7 cm in height; pileus $2.7-2.9 \mathrm{~cm}$ broad ..................... radiata $\mathbf{8}^{\prime}$ Carpophores large, $10-16 \mathrm{~cm}$ in height; pileus $1.7-5 \mathrm{~cm}$ broad.........C. radiata var. macrocarpa 9 Carpophores small, up to $5.5 \mathrm{~cm}$ in height; odor strong, disagreeable; basidiospores ellipsoidal in 
face view, with a central germ pore; pileal veil elements with nipple-shaped warts that do not


9' Carpophores larger; odor not distinctive to mild; basidiospores limoniform-subhexagonal in face view; pileal veil elements smooth or with crystals that dissolve in dilute $\mathrm{HCl}$........................10 10 Pileus not plicate-grooved, umbonate; pleurocystidia and clamp connections present...........11 10' Pileus 1.4-1.8 cm broad, plicate-grooved, exumbonate; pleurocystidia and clamp connections absent; basidiospores $8.5-13 \times 5-8.5 \mu \mathrm{m} \ldots \ldots \ldots \ldots \ldots \ldots \ldots \ldots \ldots . . \ldots \ldots \ldots$. cothurnata var. equsterca 11 Basidiospores $12-15.3 \times 8.5-12.7 \mu \mathrm{m}$, cheilocystidia $29-71 \times 17-42.4 \mu \mathrm{m}$; pleurocystidia 2463 x 15-42.4 11' Basidiospores 9.2-12.8 × 8.5-11 $\mu \mathrm{m}$, cheilocystidia 28-57 × 14-26 $\mu \mathrm{m}$; pleurocystidia 25-65 $\times 11.4-28.4 \mu \mathrm{m}$.

C. pseudonivea

\section{Taxonomic descriptions}

Coprinopsis vermiculifera (Joss.: Dennis) Redhead, Vilgalys and Moncalvo in Taxon 50(1): 232, 2001.

Basionym - Coprinus vermiculifer Josserand in Bull. Soc. Mycol. France 60: 5, 1945.

Figs. 1-2 Synonym - Coprinus vermiculifer Josserand: Dennis in Kew Bull. 19(1): 112, 1964.

Carpophores $2.8-3 \mathrm{~cm}$ in height; Pileus $1.4-1.7 \mathrm{~cm}$ broad, $1.5-1.8 \mathrm{~cm}$ high, campanulate with plane apex; surface dry, brownish gray $\left(6 \mathrm{E}_{2}\right)$; pileal veil scaly, scales grayish white, appressed fibrillose covering the entire pileus surface; margin regular, splitting, striated; cuticle half peeling; flesh up to $0.1 \mathrm{~cm}$ thick, pale white, unchanging; taste and odor not distinctive. Lamellae free, unequal, 3-sized, crowded, narrow, $0.1-0.2 \mathrm{~cm}$ broad, white when young, black at maturity. Stipe central, $2.5-2.8 \mathrm{~cm}$ long, $0.7-0.9 \mathrm{~cm}$ broad, tapering upwards, with distinctly bulbous base, first solid then hollow, surface white $\left(6 \mathrm{~A}_{1}\right)$, unchanging, pruinose.

Basidiospores (9.3)10-13.6 $\times(6.8) 7.6-9.3 \mu \mathrm{m}(\mathrm{Q}=1.4)$, ellipsoidal, with central germ pore, thick-walled, smooth, reddish brown, bleaching in concentrated $\mathrm{H}_{2} \mathrm{SO}_{4}$. Basidia dimorphic, short clavate measuring $17-22 \times 12-13.6 \mu \mathrm{m}$ and pedicellate clavate measuring $27-37 \times 10-12.7$ $\mu \mathrm{m}$, all 4-spored, thin walled, irregularly granular; sterigmata $2.5-4.3 \mu \mathrm{m}$ long; surrounded by inflated, 2-, 3- to 4- pseudoparaphyses. Gill edges sterile. Cheilocystidia 39-59.5 × 27-35.7 $\mu \mathrm{m}$, inflated clavate to globose-ellipsoidal, thin-walled, hyaline. Pleurocystidia 34-85 $\times 25.4-37.4 \mu \mathrm{m}$, abundant, inflated clavate, thin-walled, hyaline. Pileus cuticle a cutis with hyphal veil; velar remnants arranged in chains, erect, branched, thick walled, granular 5-10 $\mu \mathrm{m}$ broad, with clamp connections; pileus context homoiomerous, made up of repent, radially arranged, narrow, thin walled, hyaline 4.3-9.3 $\mu \mathrm{m}$ broad hyphae. Hymenophoral trama regular, composed of parallel, thin walled, hyaline hyphae. Subhymenium pseudoparenchymatous. Stipe cuticle hyphal, smooth, context made up of longitudinally arranged, thin-walled, hyaline, 3.4-18.4 $\mu \mathrm{m}$ broad hyphae. Clamp connections present throughout.

Material examined - India, Punjab, Hoshiarpur, Garhshankar, alt. 295 m, growing in a group on buffalo dung, 05 July 2011, Amandeep Kaur, PUN 4833.

Discussion - The above examined collection is typical of $C$. vermiculifera (Uljé \& Noordeloos 1997). It possesses large basidiospores, branched thick walled velar hyphae arranged in chains on the pileus cuticle and coprophilous habitat.

C. vermiculifera has been reported to occur on sheep dung by Orton \& Watling (1979) and from dung of deer and elephant in Europe and Africa by Uljé \& Noordeloos (1997). It is also known from South Georgia, United Kingdom (Pegler et al. 1980) and Australia (May \&Wood 1997). Doveri (2010) recorded it growing on goat dung from Italy. Watling \& Richardson (2010) have recorded this species growing on cattle dung from Sea Lion Island, East Falkland. Presently, carpophores were collected growing on buffalo dung from India. It is apparent that this mushroom can colonize on all sorts of herbivore dung. 

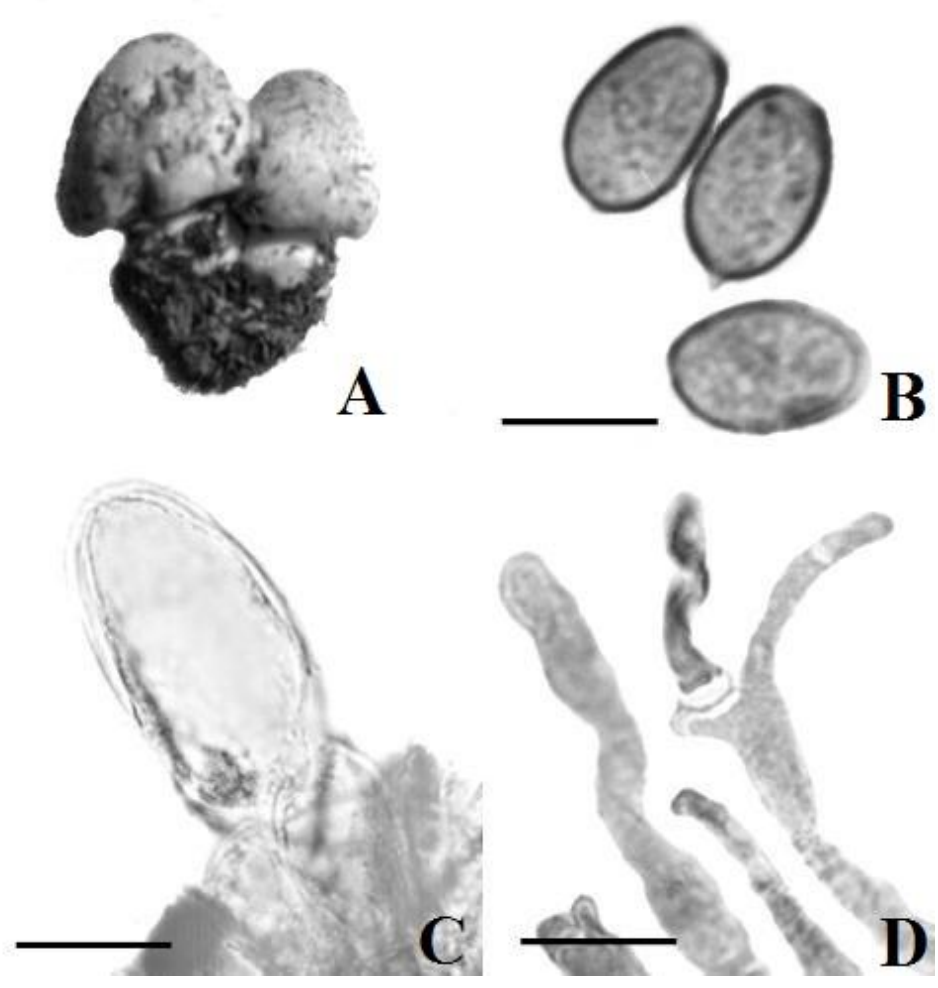

Fig. 1 - Coprinopsis vermiculifera. A Carpophores; B Basidiospores; C Pleurocystidium; D Pileal veil showing branched hyphae with clamp connection at the base. Bars B-D $20 \mu \mathrm{m}$

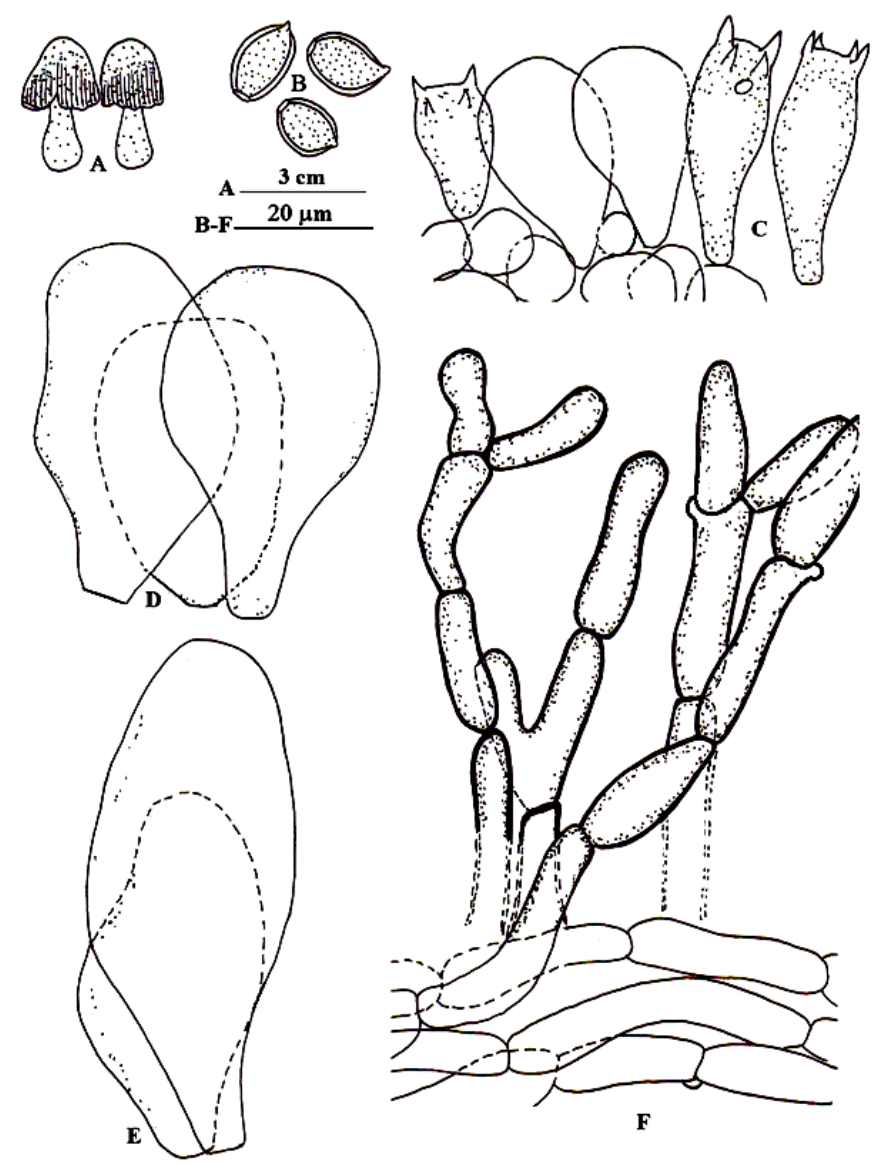

Fig. 2 - Coprinopsis vermiculifera. A Carpophores; B Basidiospores; C Basidia and Pseudoparaphyses; D Cheilocystidia; E Pleurocystidia; F Pileal cuticular elements. 
Coprinopsis scobicola (P.D. Orton) Redhead, Vilgalys and Moncalvo in Taxon 50(1): 231, 2001.

Figs. $3-4$

Basionym - Coprinus scobicola P.D. Orton in Notes R. Bot. Gdn. Edinb. 32: 147, 1972.

Carpophore $5.7 \mathrm{~cm}$ in height; Pileus $3.4 \mathrm{~cm}$ broad, $3.3 \mathrm{~cm}$ high, campanulate; surface dry, with white $\left(6 \mathrm{~A}_{1}\right)$ background; pileal veil scaly, scales grayish brown $\left(6 \mathrm{D}_{3}\right)$, brown $\left(6 \mathrm{D}_{5}\right)$ at the apex, appressed fibrillose, covering the entire pileus surface, more aggregated around the apex, removable on touching; margin irregular, splitting, striated up to the apex; cuticle not peeling; flesh thin, white, becoming black when handled; taste and odor not distinctive. Lamellae free, unequal, crowded, moderately broad, up to $0.5 \mathrm{~cm}$ broad, fragile, deliquescent, white $\left(6 \mathrm{~A}_{1}\right)$, becoming grayish black where handled. Spore print black. Stipe central, $5.5 \mathrm{~cm}$ long, $0.8 \mathrm{~cm}$ broad, obclavate, with a very small pseudorrhiza at the base, hollow, surface white, unchanging, fibrillose.

Basidiospores 10-12.7 $\times 6.8-8.5 \mu \mathrm{m}(\mathrm{Q}=1.48)$, ellipsoidal, with a central germ pore, thick-walled, smooth, dark brown, bleaching in concentrated $\mathrm{H}_{2} \mathrm{SO}_{4}$. Basidia 15.3-23.8 $\times 6.8-11$ $\mu \mathrm{m}$, clavate, 2-spored, very rarely 4-spored, thin walled, granular; sterigmata 3.4-5 $\mu \mathrm{m}$ long; surrounded by sphaeropedunculate thin walled pseudoparaphyses. Gill edges heteromerous. Cheilocystidia 32.3-63 $\times 20.5-42.5 \mu \mathrm{m}$, subglobose to ellipsoidal, thick-walled, walls wider towards the apex, granular. Pleurocystidia 71.4-102 × 29-35.7 $\mu \mathrm{m}$, abundant, polymorphic, cylindrical, elongated clavate, or even ventricose fusoid, thick-walled, irregularly granular. Pileus cuticle a cutis having veil in the form of hyphal chains; velar hyphae unbranched, erect, elongated cylindrical, septate, thin walled, granular near the walls, $10-15.3 \mu \mathrm{m}$ broad; pileus context homoiomerous, composed of filamentous, radially arranged, intermingled, thin walled, hyaline 8.5$23.8 \mu \mathrm{m}$ broad hyphae. Hymenophoral trama subregular, composed of thin walled hyaline 3.4-13.6 $\mu \mathrm{m}$ broad hyphae. Subhymenium pseudoparenchymatous. Stipe cuticle hyphal; context composed of compactly arranged, longitudinally tangled, thin-walled, hyaline 3.4-13.6 $\mu \mathrm{m}$ broad hyphae. Clamp connections present in stipe context hyphae.

Material examined - India, Punjab, Sangrur, Meemsa, alt. 231 m, growing solitary on sheep dung, 25 July 2010, Amandeep Kaur, PUN 4832.

Discussion - The above examined collection is characteristic of $C$. scobicola (Uljé \& Noordeloos 1999) except for the presence of occasional 4-spored basidia in the Indian collection. It is recognized by the presence of mostly 2 -spored basidia and unbranched, elongated cylindrical hyphal veil. C. bicornis is a similar species with $2-$ spored basidia and growth on dung but differs in having mixed hyphal and cellular velar remnants (Uljé \& Noordeloos 1999).

Coprinopsis scobicola was reported to occur on sawdust and compost from England and Scotland in United Kingdom (Uljé \& Noordeloos 1999). During the present investigation the species was found growing solitary on sheep dung during late July.

Coprinopsis lagopus (Fr.) Redhead, Vilgalys and Moncalvo in Taxon 50(1): 229, 2001.

Basionym - Agaricus lagopus Fries in Systema Mycologicum 1: 312, 1821.

Figs. $5-6$ Synonym - Coprinus lagopus (Fries) Fries in Epicrisis p. 250, 1838.

Carpophores 3-9 cm in height; Pileus $0.9-2.4 \mathrm{~cm}$ broad, campanulate when young, applanate at maturity, finally plano-concave with reflexed margin; umbonate, umbo broad, brown; surface moist, first white, later gray $\left(6 \mathrm{~B}_{1}\right)$; pileal veil white, powdery and appressed fibrillose, covering the entire pileus surface, removable on bruising; margin irregular, striated, splitting, reflexed at maturity; cuticle not peeling; flesh thin, membranous, white, blackening when handled or with age; taste and odor mild. Lamellae free to adnexed, unequal, subdistant, moderately broad, deliquescent, white when young, black at maturity. Spore print black. Stipe central, $2.9-8.9 \mathrm{~cm}$ long, $0.2-0.35 \mathrm{~cm}$ broad, tapering upwards, with slightly bulbous base, hollow, surface white, unchanging, pruinose fibrillose; exannulate.

Basidiospores 10-13.6 ×6.8-9.3 $\mathrm{m}(\mathrm{Q}=1.46)$, ellipsoidal, with a broad central germ pore, thick-walled, smooth, dark brown; apiculus 0.85-1.7 $\mu \mathrm{m}$ long. Basidia dimorphic, short ellipsoidal 


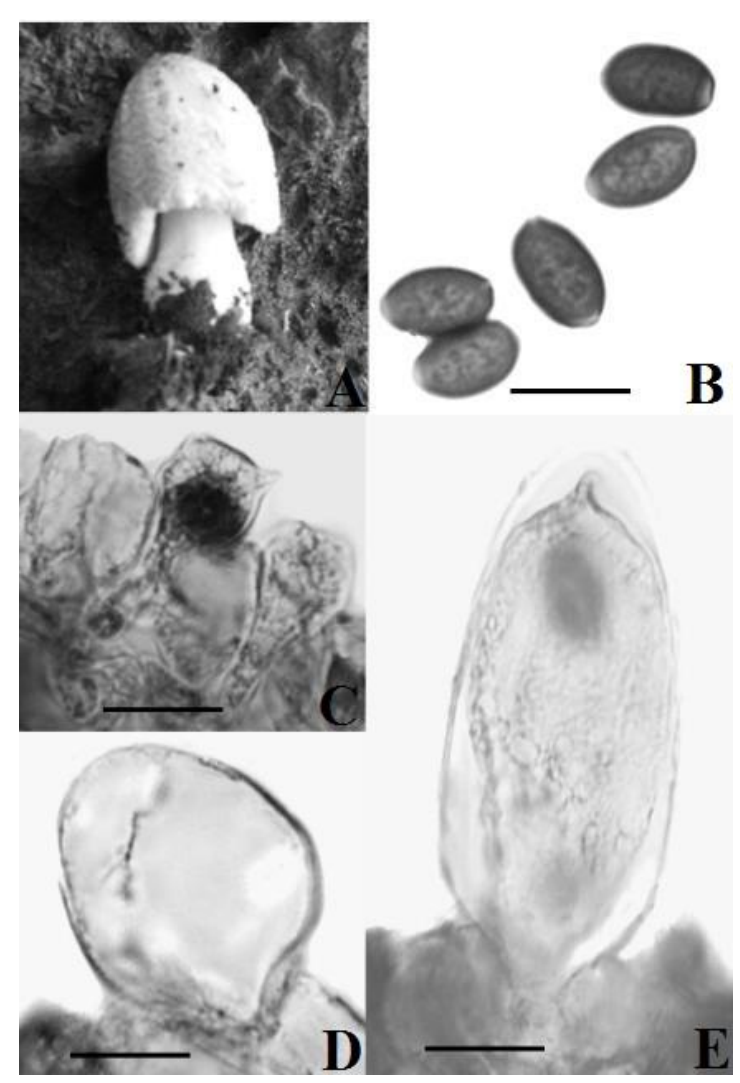

Fig. 3 - Coprinopsis scobicola. A Carpophore; B Basidiospores; C Basidia and Pseudoparaphyses; D Cheilocystidium; E Pleurocystidium. Bars B-E $20 \mu \mathrm{m}$

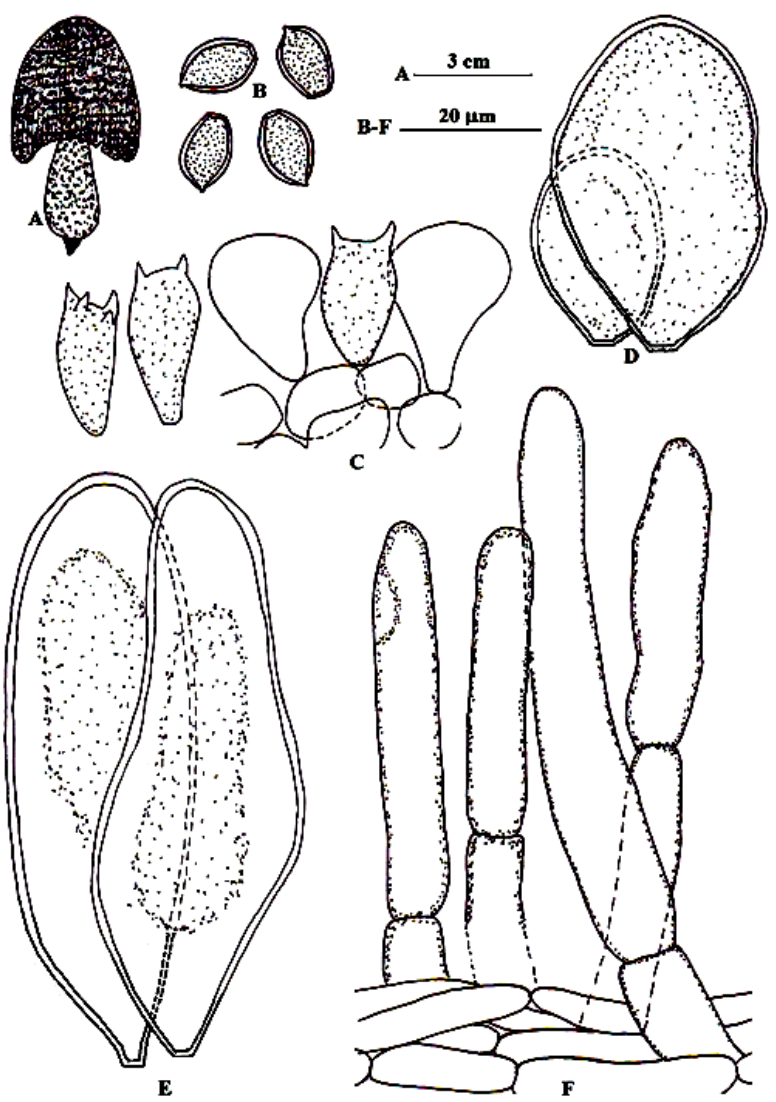

Fig. 4 - Coprinopsis scobicola. A Carpophore; B Basidiospores; C Basidia and Pseudoparaphyses; D Cheilocystidia; E Pleurocystidia; F Pileal elements. 


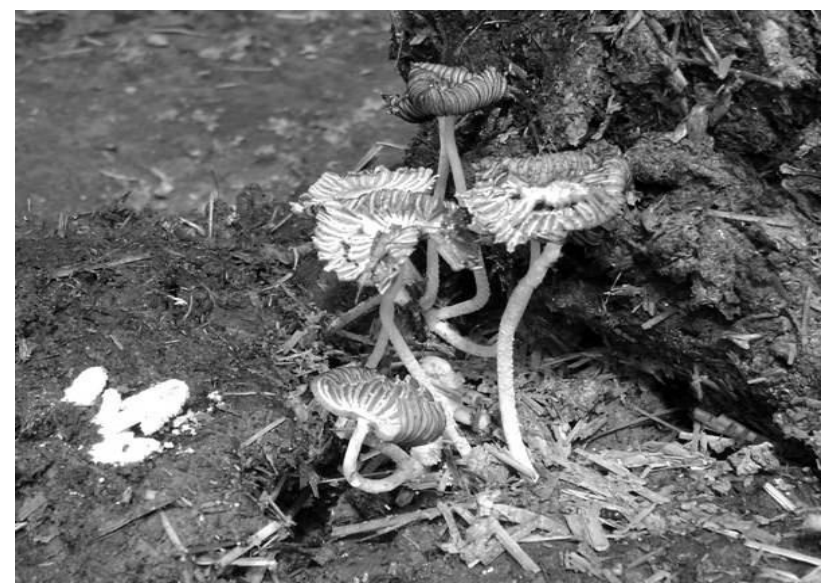

Fig. 5 - Coprinopsis lagopus. Carpophores growing in natural habitat.

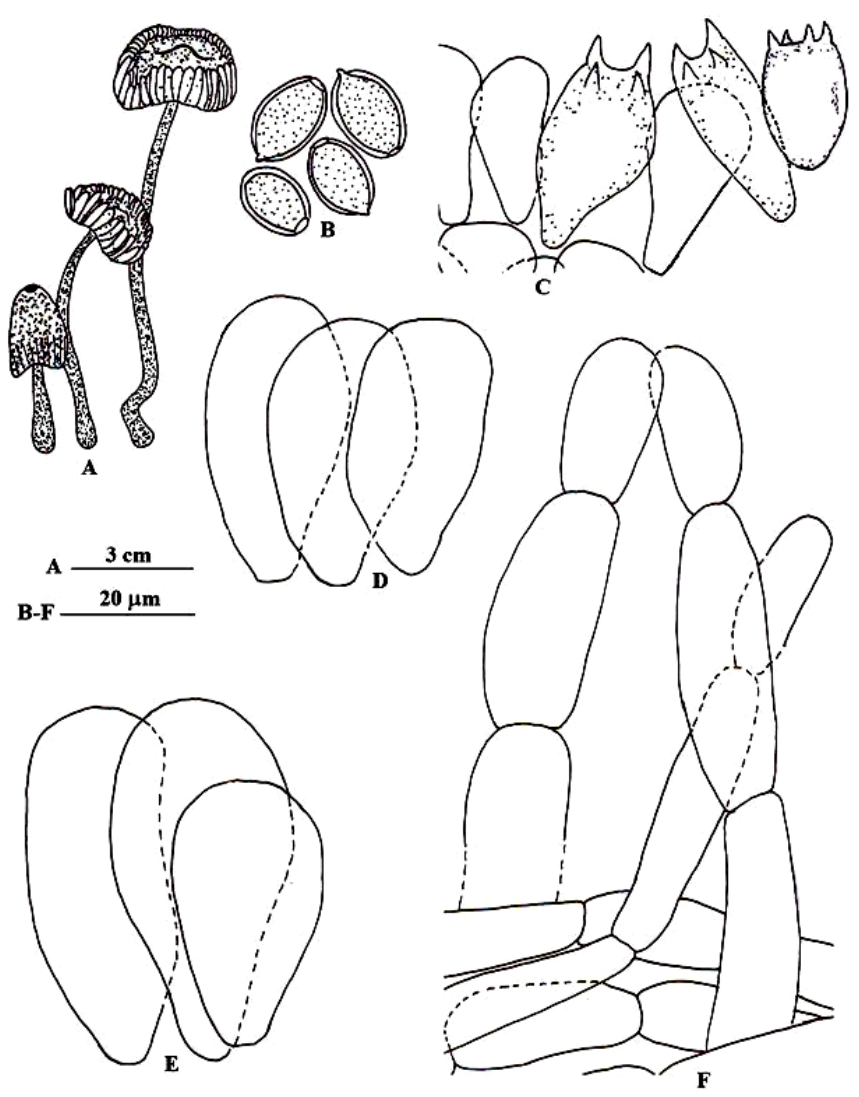

Fig. 6 - Coprinopsis lagopus. A Carpophores; B Basidiospores; C Basidia and Pseudoparaphyses; D Cheilocystidia; E Pleurocystidia; F Pileal cuticular elements.

measuring $12.8-17 \times 8.5-11.5 \mu \mathrm{m}$ in size, elongated clavate measuring $18.7-32.3 \times 11-15.3 \mu \mathrm{m}$ in size, all 4-spored, thin walled, weakly granular, surrounded by $2-$ to 3 - pseudoparaphyses; sterigmata 2.5-3.4(4.3) $\mu \mathrm{m}$ long. Gill edges heteromerous. Cheilocystidia 25.5-40.8 $\times 15.3-21.2$ $\mu \mathrm{m}$, ellipsoidal to inflated clavate, thin-walled, hyaline. Pleurocystidia 32.3-52.7 $\times 12-29 \mu \mathrm{m}$, inflated clavate, thin-walled, hyaline. Pileus cuticle a cutis, with hyphal veil arranged in chains; velar remnants filamentous, cylindrical, thin walled, hyaline $6.8-22 \mu \mathrm{m}$ broad; context homoiomerous, composed of radially arranged, cylindrical to ellipsoidal, thin walled, 12-25.5 $\mu \mathrm{m}$ broad hyaline hyphae. Hymenophoral trama composed of parallel, thin walled, hyaline 4.3-11 $\mu \mathrm{m}$ broad hyphae. Subhymenium pseudoparenchymatous. Stipe context hyphae longitudinally tangled, thin-walled, hyaline, 7.6-18.7 $\mu \mathrm{m}$ broad. Clamp connections present in stipe context hyphae. 
Material examined - India, Punjab, Sangrur, Amargarh, alt. $231 \mathrm{~m}$, growing in groups on mixed cattle dung, 21 June 2008, Amandeep Kaur, PUN 4819.

Discussion - The macroscopic and microscopic details of the presently examined collection are in conformity with C. lagopus (Pegler 1977, Uljé \& Noordeloos 1999). It is commonly referred as harefoot mushroom because of its young carpophores which are reported to resemble the paw of a white rabbit (Crosier et al. 1949). It is reported to be edible with good flavor (Bhavani Devi 1995).

According to Uljé \& Noordeloos (1999), C. lagopus is a common species growing solitary or in clusters all over the world on wood-chips, compost-heaps, vegetable refuse etc. Pegler (1977) reported it growing on the ground in the month of March from Kenya. Keirle et al. (2004) reported it growing densely gregarious on older woodchip piles from Hawaiian Islands. Earlier records of this species from India are by Krishnamoorthy \& Verma (1974) from New Delhi, Natarajan \& Raaman (1983) from Tamil Nadu, Bhavani Devi (1995) from Kerala and Atri \& Kaur (2004) from Punjab.

Coprinopsis lagopides var. lagopides (P. Karst.) Redhead, Vilgalys and Moncalvo in Taxon 50(1): 229, 2001.

Basionym - Coprinus lagopides P. Karsten in Meddel. Soc. Fauna Fl. Fenn. 5: 23, 1879.

Carpophores up to $3 \mathrm{~cm}$ in height; Pileus up to $2 \mathrm{~cm}$ broad, $1.8 \mathrm{~cm}$ high when still closed, conical to campanulate; surface moist, white $\left(6 \mathrm{~A}_{1}\right)$ to brownish gray $\left(6 \mathrm{E}_{2}\right)$, dark brown $\left(6 \mathrm{~F}_{5}\right)$ at the apex; pileal veil scaly, scales silvery gray, appressed fibrillose, covering the entire pileus surface, removable; margin lighter in color, irregular, splitting, striated up to half from the apex; cuticle half-peeling; flesh thin, changing to grayish black when handled; taste and odor mild. Lamellae adnexed, equal, crowded, narrow, deliquescent, first white, soon grayish black. Spore print black. Stipe up to $2.6 \mathrm{~cm}$ long, $0.5-0.6 \mathrm{~cm}$ broad, obclavate, tapering upwards, first solid then hollow, surface white $\left(6 \mathrm{~A}_{1}\right)$, unchanging, pruinose to finely powdery; annulus absent.

Basidiospores 7-8.5 $\times 5-6.4 \mu \mathrm{m}(\mathrm{Q}=1.35)$, ovoid to ellipsoidal, with an apical germ pore, thick-walled, smooth, reddish brown to blackish brown; apiculus short, $0.7 \mu \mathrm{m}$ long. Basidia dimorphic, short clavate measuring 11.4-17 $\times 5.7-7 \mu \mathrm{m}$, elongated cylindrical to clavate measuring 17-24.2 × 5.7-8.5 $\mu \mathrm{m}, 4$-spored, thin-walled, hyaline; sterigmata 2-3.6 $\mu \mathrm{m}$ long. Gill edges heteromerous. Cheilocystidia 54-71 $\times 23-30 \mu \mathrm{m}$, obclavate or ellipsoidal, with rounded ends, thinwalled, hyaline. Pleurocystidia 31-78 $\times 18.5-35.5 \mu \mathrm{m}$, similar to cheilocystidia, oblong, ellipsoidal to ovoid, flattened, thin-walled, hyaline. Pileus cuticle a cutis supporting hyphal veil all over the pileus surface; velar remnants composed of unbranched, septate, cylindrical to inflated, thinwalled, hyaline hyphae measuring $42.6-92.3 \times 5.7-21.3 \mu \mathrm{m}$ in size; uppermost cell with tapering apex, sometimes with golden brown incrustations; pileus context homoiomerous, made up of radially oriented, cylindrical to inflated, thin-walled 11.4-22.7 $\mu \mathrm{m}$ broad hyphae. Hymenophoral trama regular, composed of thin-walled, hyaline 5-7.8 $\mu \mathrm{m}$ broad hyphae. Stipe cuticle hyphal, smooth, context made up of longitudinally tangled, septate, thin-walled 8.5-32.7 $\mu \mathrm{m}$ broad hyphae. Clamp connections present on stipe context and veil hyphae.

Material examined - India, Punjab, Sangrur, Naushehra, alt. $231 \mathrm{~m}$, scattered on mixed cattle dung and straw heap, 09 July 2007, Amandeep Kaur, PUN 4060.

Discussion - The above-examined collection is typical of C. lagopides var. lagopides (Van de Bogart 1979). Coprinopsis lagopides var. trisporus can be differentiated from it in having mostly 3-spored basidia. Coprinopsis brunneistrangulatus is also very closely related but differs from the present species in having spores with thick, pigmented perisporium and more grayish carpophores.

Coprinopsis lagopides var. lagopides has been reported growing solitary or in small groups on soil or woody debris in Western United States (Van de Bogart 1979). Orton (1957) collected the species from burnt soil. Previous records of this species from India are by Watling \& Gregory (1980) and Abraham (1991) from North West Himalayas. 


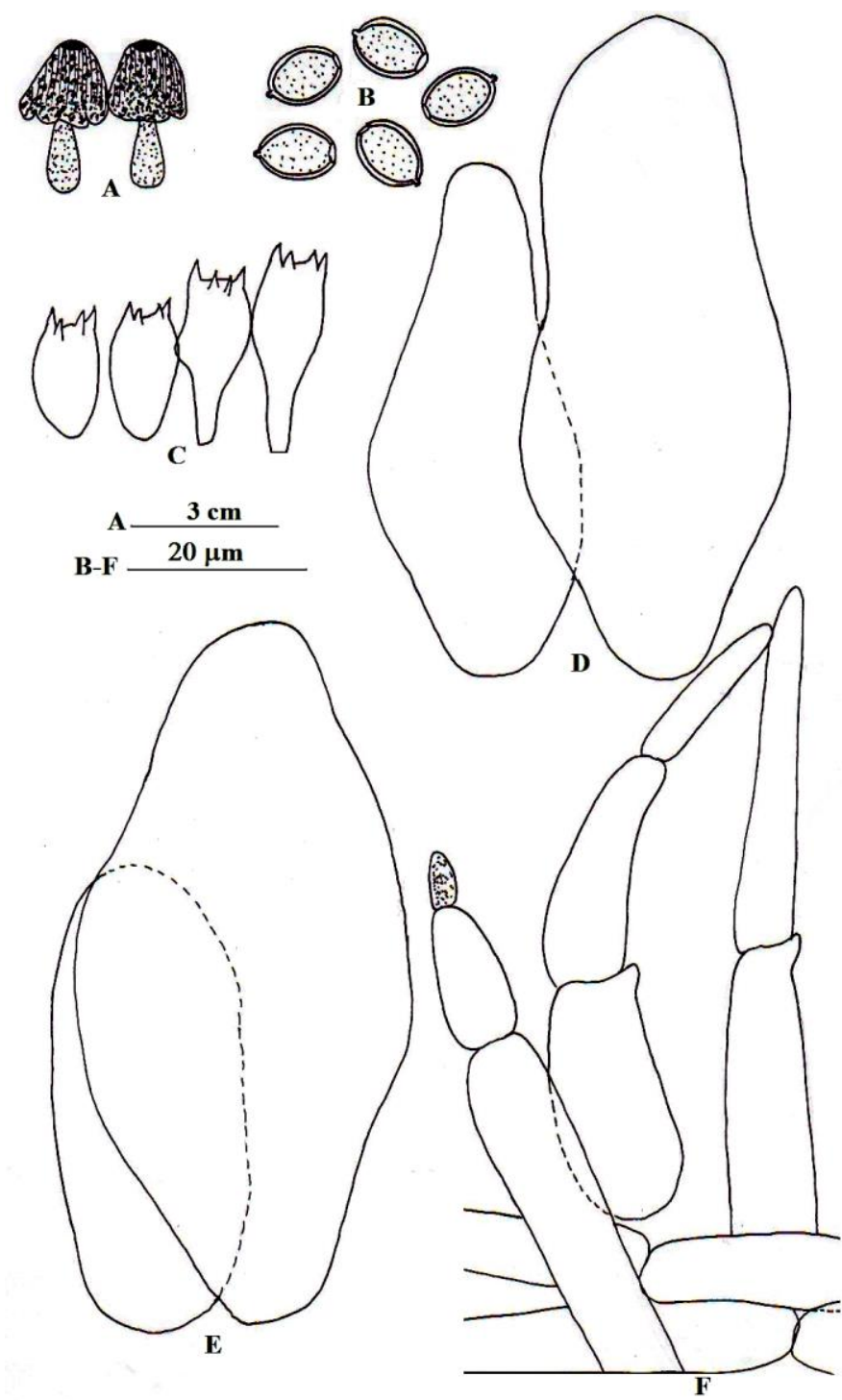

Fig. 7 - Coprinopsis lagopides var. lagopides. A Carpophores; B Basidiospores; C Basidia; D Cheilocystidia; E Pleurocystidia; F Pileal elements.

Coprinopsis macrocephala (Berk.) Redhead, Vilgalys and Moncalvo in Taxon 50(1): 229, 2001.

Figs. 8-9

Basionym - Agaricus macrocephalus Berkeley in The English Flora Fungi 5: 122, 1836.

Synonym - Coprinus macrocephalus (Berkeley) Berkeley in Outlines of British Fungology p. 180, 1860.

Carpophores 10.2-14.7 $\mathrm{cm}$ in height; Pileus $2.8-3.7 \mathrm{~cm}$ broad, 2-3 cm high, elongated ellipsoidal when young, convex to applanate at maturity; surface moist, greenish gray $\left(27 \mathrm{E}_{2}\right)$ to blackish gray, with brown $\left(6 \mathrm{E}_{6}\right)$ apex; pileal veil scaly, scales grayish white, appressed fibrillose to recurved fibrillose, in concentric rings when young, covering the entire pileus surface, removable on touching; margin irregular, splitting, striated; cuticle not peeling; flesh thin, changing to black liquid at maturity; taste and odor not distinctive. Lamellae free, unequal, crowded, narrow, up to $0.2 \mathrm{~cm}$ broad, deliquescent, white when young, black at maturity. Spore print black. Stipe central, 9.8-14.5 cm long, 0.6-1.0 cm broad, cylindrical, bulbous at the base, tapering downwards to form a pseudorrhiza, hollow, surface white, unchanging, fibrillose; pseudorrhiza small, white, $1.3 \mathrm{~cm}$ long, solid; exannulate.

Basidiospores 12-15.3 × 8.5-10 $\mu \mathrm{m}(\mathrm{Q}=1.47)$, ellipsoidal, with a broad central germ pore, thick-walled, smooth, dark reddish brown; apiculate, apiculus eccentrically placed. Basidia 


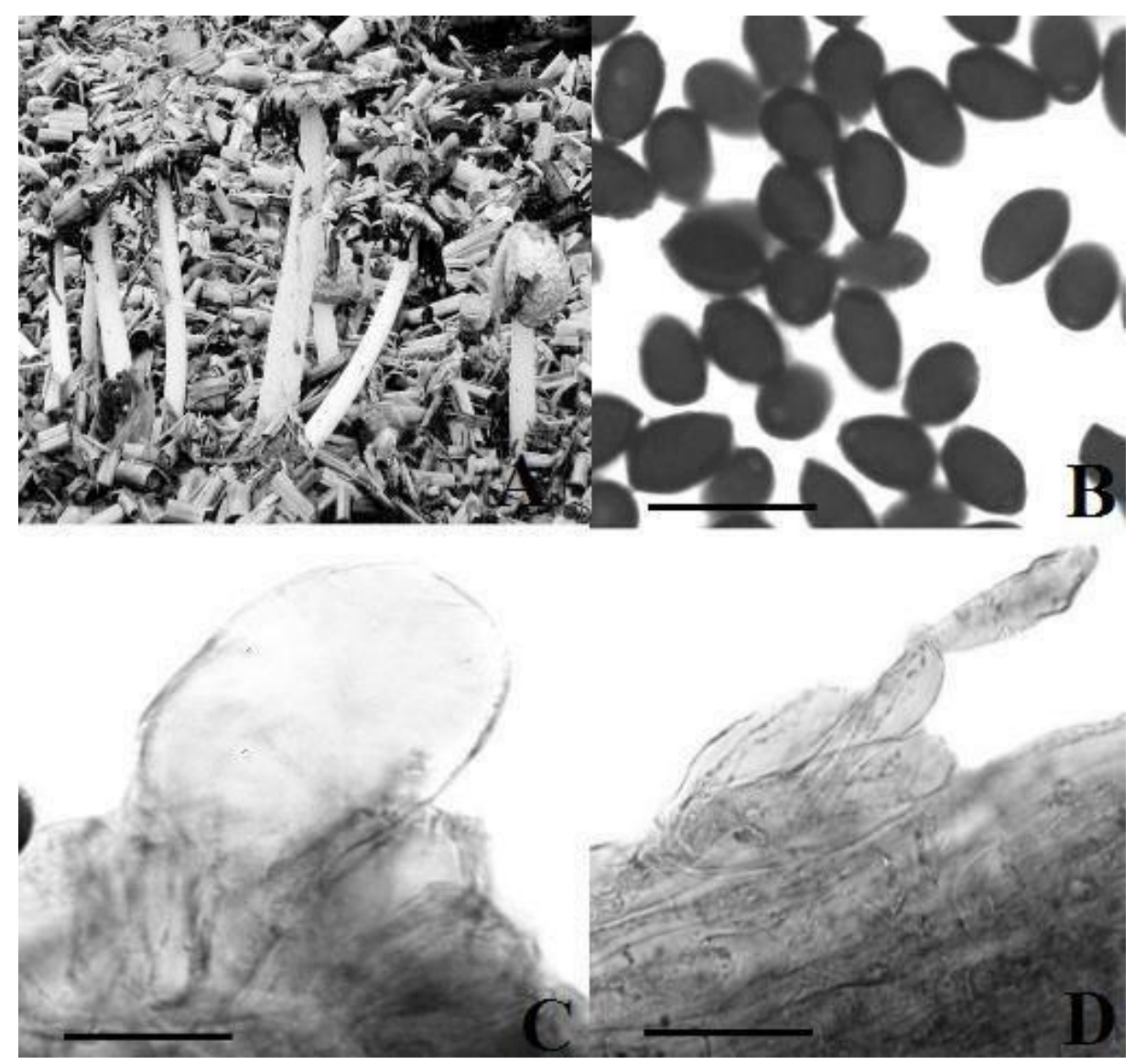

Fig. 8 - Coprinopsis macrocephala. A Carpophores; B Basidiospores; C Pleurocystidium; D Pileal veil. Bars B-D $20 \mu \mathrm{m}$

dimorphic, short basidia clavate, measuring 17-22 × 13.6-16 $\mu \mathrm{m}$, larger basidia elongate clavate, measuring 29-36 × 12.7-15.3 $\mu \mathrm{m}$, all 4-spored, thin-walled, hyaline, surrounded by pseudoparaphyses; sterigmata 2.5-3.4 $\mu \mathrm{m}$ long. Gill edges sterile. Cheilocystidia 34-60 × 16-29 $\mu \mathrm{m}$, ellipsoidal to inflated clavate, thin-walled, hyaline. Pleurocystidia 49-102 $\times 22-42.5 \mu \mathrm{m}$, inflated clavate, thin-walled, hyaline. Pileus cuticle a cutis with elongated velar remnants forming long chains all over the surface; veil elements unbranched, cylindrical to ellipsoidal, septate, some with clamp connection at the septa, thin-walled, granular with brown incrustations, 8.5-15.3 $\mu \mathrm{m}$ broad; context homoiomerous, made up of radially intermingled, thin-walled, 10-22 $\mu \mathrm{m}$ broad hyphae. Stipe context hyphae longitudinally tangled, thin-walled, hyaline $7-18.7 \mu \mathrm{m}$ broad. Clamp connections present throughout.

Material examined - India, Punjab, Jalandhar, Rahimpur, alt. 233 m, growing in scattered groups on mixed cattle dung and straw residue heap, 30 July 2010, Amandeep Kaur, PUN 4820.

Discussion - The above examined collection has been identified as C. macrocephala. Its macroscopic and microscopic characters are in conformity with those given for this species by Pegler (1986) and Uljé \& Noordeloos (1999). Pegler (1986) documented spore size range from $10.5-12.5 \times 7-9 \mu \mathrm{m}$ in the Sri Lankan material as compared to12-15.3 $\times 8.5-10 \mu \mathrm{m}$ sized spores in the presently examined collection. Arora (1986) documented larger spores (11-16 $\mu \mathrm{m}$ long) which are comparable in size to the spores of the Indian collection of $C$. macrocephala. Similarly Uljé \& Noordeloos (1999) documented 12.2-16.8 $\times 8.2-9.8 \mu \mathrm{m}$ sized spores in the collection examined from the Netherlands. Coprinopsis radiata is quite similar but differs from it in having small sized carpophores and narrower basidiospores. Another species close to C. macrocephala is $C$. cinerea which differs in having smaller pseudorrhiza and larger basidiospores in comparison to this species. C. lagopus is also close to it but differs in having non-radicating stipe. 


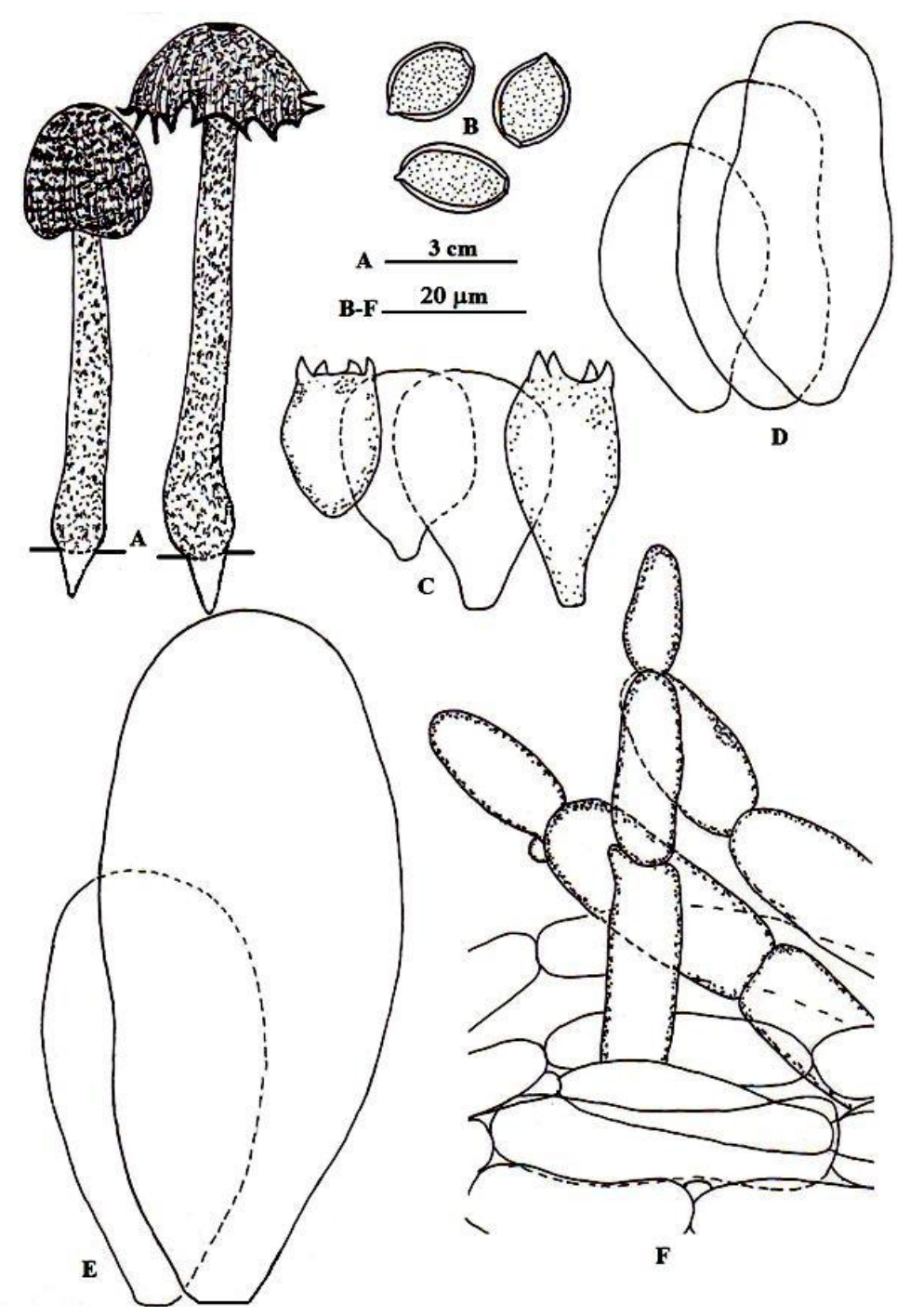

Fig. 9 - Coprinopsis macrocephala. A Carpophores; B Basidiospores; C Basidia; D Cheilocystidia; E Pleurocystidia; F Pileal elements.

Pegler (1986) reported C. macrocephala growing on garbage heap in the month of November from Kandy, Sri Lanka. Uljé \& Noordeloos (1999) documented it growing solitary or in fascicles on mixed dung, rotten vegetable refuse and even on pure dung in the months of May, December and February from the Netherlands. Türkoğlu et al. (2007) reported it growing on horse manure, in the month of May from Kayseri, Turkey. Doveri (2010) recorded this species growing on bovine and equine dung and also on straw and manure from Italy. Natarajan \& Raaman (1983) reported it growing in groups on the ground during March from Tamil Nadu, South India. Presently it is being recorded growing scattered on mixed cattle dung and straw residue heap in the month of July for the first time from North India.

Coprinopsis cinerea (Schaeff.) Redhead, Vilgalys and Moncalvo in Taxon 50(1): 227, 2001.

Figs. $10-11$

Basionym - Agaricus cinereus Schaeffer in Fung. Bavar. Palat. Nasc. 4: 43, 1774.

Synonyms - Agaricus radians Batsch in Elenchus fungorum p. 61, 1783.

Agaricus macrorhizus Persoon in Observationes mycologicae 1: 47, 1796.

Coprinus cinereus (Schaeffer) Gray in A natural arrangement of British plants 1: 634, 1821.

Coprinus fimetarius var. cinereus (Schaeffer) Fries p. 246, 1838.

Coprinus macrorhizus (Pers.) Rea in British Basidiomycetae p. 503, 1922.

Coprinus delicatulus Apinis in Trans. Brit. Mycol. Soc. 48(4): 653, 1965. 


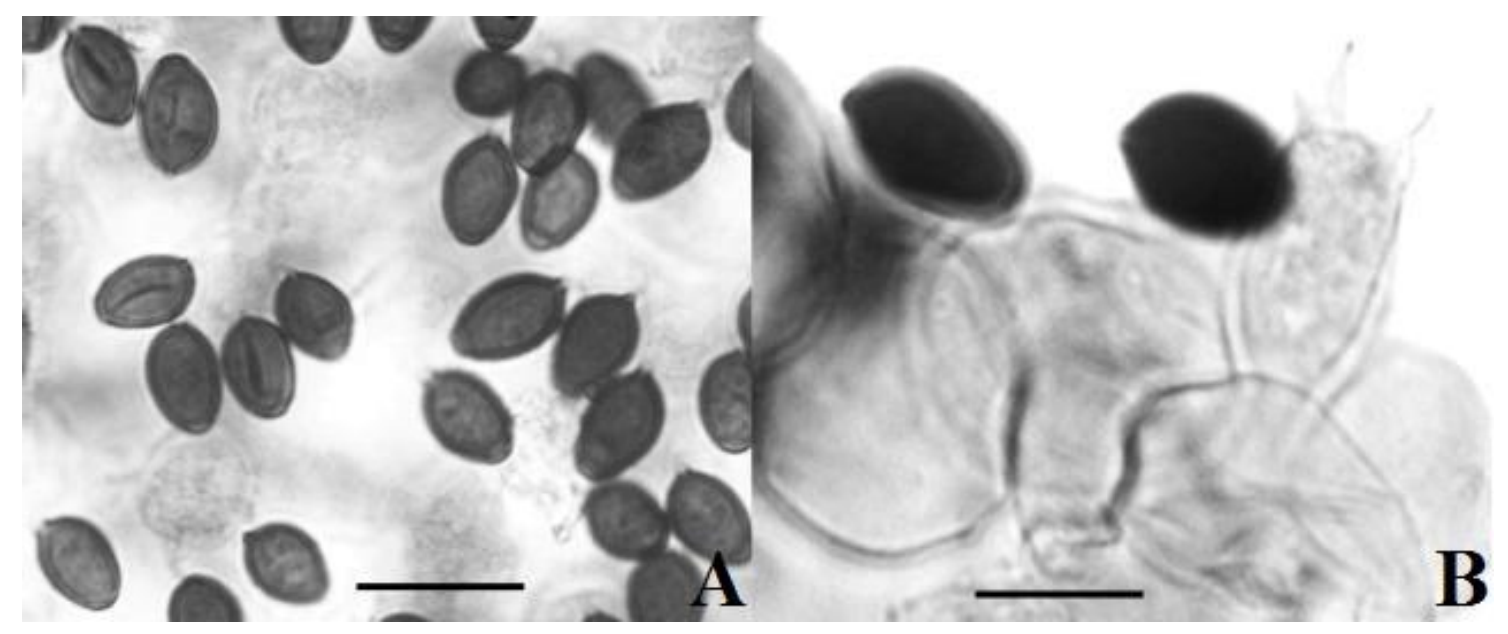

Fig. 10 - Coprinopsis cinerea. A Basidiospores; B Heteromorphous gill edge showing cheilocystidia and basidia. Bars A-B $20 \mu \mathrm{m}$

Carpophores $6.8-9 \mathrm{~cm}$ in height; Pileus $1.8-3.8 \mathrm{~cm}$ broad, $2.5-3.4 \mathrm{~cm}$ high, campanulate to convex, with slightly raised apex; surface moist, gray $\left(6 \mathrm{~B}_{1}\right)$ to grayish brown $\left(6 \mathrm{E}_{3}\right)$, light brown $\left(6 \mathrm{D}_{4}\right)$ at the apex; pileal veil scaly, scales whitish, loosely appressed and easily removable, covering the entire pileus surface, more aggregated around the apex; margin irregular, radially splitting, striated; flesh thin, blackening at maturity; taste and odor mild. Lamellae free, unequal, crowded, narrow, deliquescent, white when young, grayish black at maturity. Spore print black. Stipe central, $6.5-8.7 \mathrm{~cm}$ long, $0.5-0.8 \mathrm{~cm}$ broad, tapering upwards, base bulbous with tapering pseudorrhiza, hollow, surface white, unchanging, fibrillose; pseudorrhiza white, solid, elongated up to $7 \mathrm{~cm}$ long; annulus absent.

Basidiospores 8.5-12 × 5-7 $\mu \mathrm{m}(\mathrm{Q}=1.7)$, ellipsoidal, with a broad central germ pore, thick-walled, smooth, brown to blackish brown. Basidia dimorphic, short basidia clavate measuring 10-14 × 7-9 $\mu \mathrm{m}$ in size, larger basidia cylindrico-clavate measuring 15.5-21.3 × 7.5$11.5 \mu \mathrm{m}$, all 4-spored, thin-walled, hyaline; sterigmata 2-3.6 $\mu \mathrm{m}$ long. Gill edges heteromorphous. Cheilocystidia 17-41.5 × 15.6-41.3 $\mu \mathrm{m}$, abundant, globose to subglobose, thin-walled, hyaline. Pleurocystidia 27-57 $\times 11.5-31.5 \mu \mathrm{m}$, elongated ellipsoidal to inflated fusoid, thin-walled, hyaline. Pileus cuticle a cutis supporting filamentous velar remnants; veil composed of 24-71 $\times 7-17 \mu \mathrm{m}$, cylindrical, ellipsoidal to inflated thin-walled hyaline hyphae, with uppermost cell tapering upwards, sometimes with clamp connection at the septa; context homoiomerous, made up of radially arranged, cylindrical, thin-walled 7-22.7 $\mu \mathrm{m}$ broad hyphae. Hymenophoral trama regular, composed of thin walled hyaline 5.7-14.2 $\mu \mathrm{m}$ broad hyphae. Subhymenium pseudoparenchymatous. Stipe cuticle hyphal, context hyphae longitudinally interwoven, thinwalled, hyaline 4-21.3 $\mu \mathrm{m}$ broad. Clamp connections present throughout.

Materials examined - India, Punjab, Sangrur, Sikanderpura, alt. $231 \mathrm{~m}$, growing in groups on mixed cattle dung, 02 June 2008, Amandeep Kaur, PUN 4816. Patiala, Kalyan, alt. 251 m, grouped on horse dung, 31 January 2010, Amandeep Kaur, PUN 4817.

Discussion - The diagnostic characters of the above examined collections including veil features, size and shape of the basidiospores, shape of cheilocystidia and habitat are typical of $C$. cinerea as described by Van de Bogart (1979) and Uljé \& Noordeloos (1999). C. macrocephala is a closely related species but differs in having larger sized spores measuring 12.2-16.8 $\times 8.2-9.8 \mu \mathrm{m}$ and ellipsoidal to oblong cheilocystidia as reported by Uljé \& Noordeloos (1999).

It is reported to grow solitary or in fasciculate clusters on heaps of mixed dung, rotten straw or vegetable refuse all over the world (Uljé \& Noordeloos 1999). Van de Bogart (1979) recorded it growing solitary to scattered on soil, dung, wood chips, forest litter from Washington. From India, this species was documented earlier by Ginai (1936) and Manjula (1983). 
Coprinopsis radiata (Bolton: Fr.) Redhead, Vilgalys and Moncalvo in Taxon 50(1): 230, 2001.

Figs. $12-13$

Basionym - Agaricus radiatus Bolton in An History of Fungusses Growing about Halifax 1: 39, 1788.

Synonyms - Agaricus radiatus Bolton: Fr. in Syst. Mycol. I: 313, 1821.

Coprinus radiatus (Bolton: Fr.) Gray in A natural arrangement of British plants 1:635, 1821.

Coprinus fimetarius Linn.: Fr. in Epicrisis p. 245, 1838.

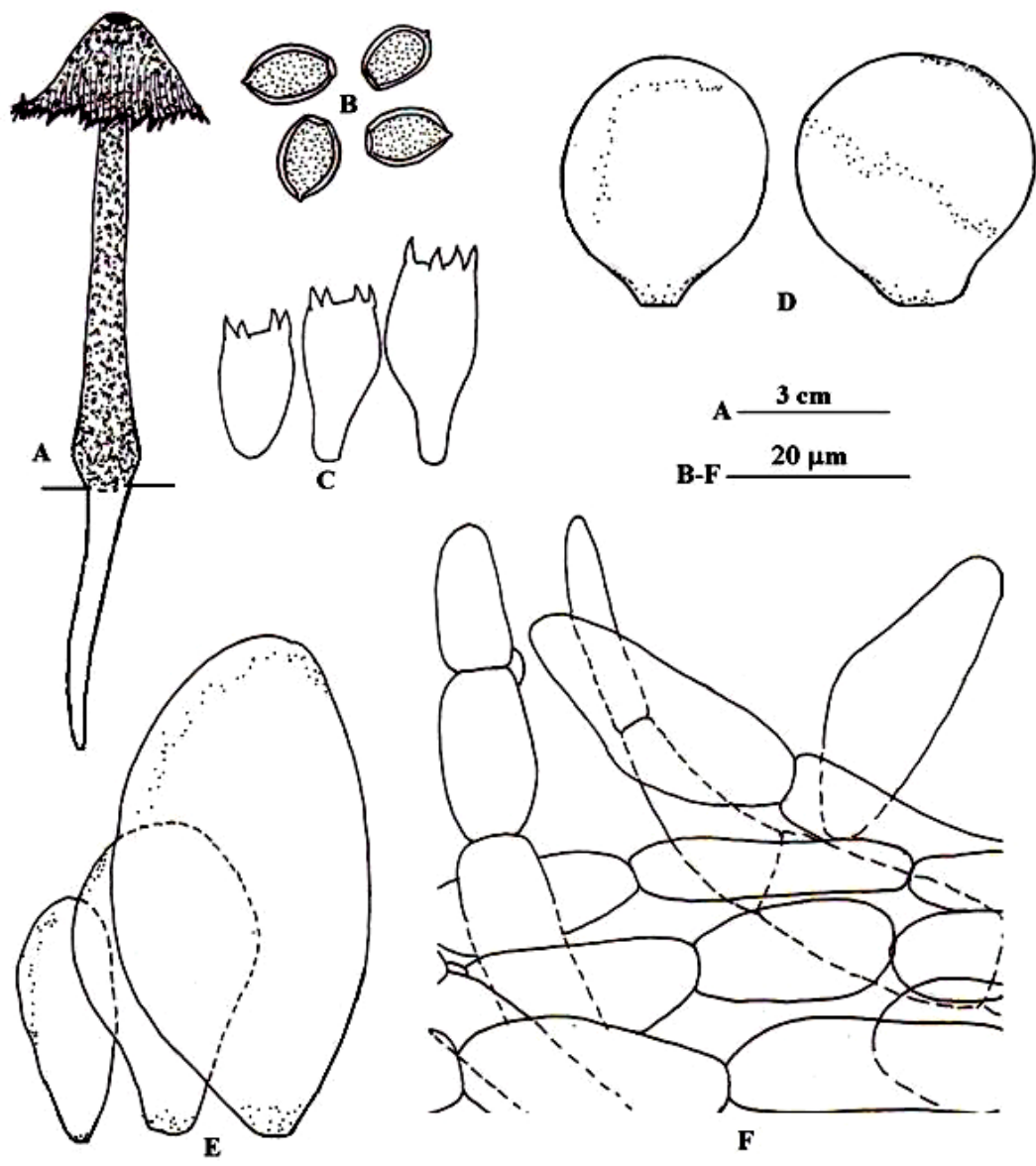

Fig. 11 - Coprinopsis cinerea. A Carpophore; B Basidiospores; C Basidia; D Cheilocystidia; E Pleurocystidia; F Pileal cuticular elements.

Carpophores 3.3-4.7 cm in height; Pileus $2.7-2.9 \mathrm{~cm}$ broad, $1.3-2 \mathrm{~cm}$ high, campanulate when young, applanate at maturity; umbonate, umbo broad, grayish brown $\left(6 \mathrm{D}_{3}\right)$; surface moist, yellowish brown $\left(5 \mathrm{E}_{8}\right)$ when young, grayish black at maturity; pileal veil scaly, scales yellowish gray, tightly adhering to the pileus surface, more aggregated along the apex; margin irregular, splitting, striate, autolytic, translucent at maturity; cuticle not peeling; flesh thin, $0.1 \mathrm{~cm}$ thick, changing to grayish black on handling; taste and odor not distinctive. Lamellae free, unequal, 4sized, subdistant, moderately broad, deliquescent, first yellowish white, finally grayish black. Spore print black. Stipe central, 3.1-4.6 cm long, $0.7-1.2 \mathrm{~cm}$ broad, cylindrical, tapering downwards to form pseudorrhiza, solid, surface white, unchanging, smooth; pseudorrhiza solid, white, up to 1.7 cm long; annulus absent.

Basidiospores $12-14.4 \times 6.8-8.5 \mu \mathrm{m}(\mathrm{Q}=1.72)$, ellipsoidal, with central germ pore, thickwalled, smooth, reddish brown. Basidia 18.7-29 × 8.5-11 $\mu \mathrm{m}$, pedicellate clavate, 4-spored, thinwalled, hyaline; sterigmata $2.5-4.3 \mu \mathrm{m}$ long. Pseudoparaphyses present. Gill edges heteromerous. Cheilocystidia 19.5-46 $\times 18.7-35.7 \mu \mathrm{m}$, ellipsoidal, clavate to inflated clavate, thin-walled, hyaline. Pleurocystidia $25.5-73 \times 19.5-44.3 \mu \mathrm{m}$, subglobose to inflated clavate, thin-walled, hyaline. Pileus cuticle a cutis with hyphal veil all over the surface; veil composed of filamentous chains of cylindrical, septate, thin-walled, hyaline 3.4-15.3 $\mu \mathrm{m}$ broad hyphae, with terminal 


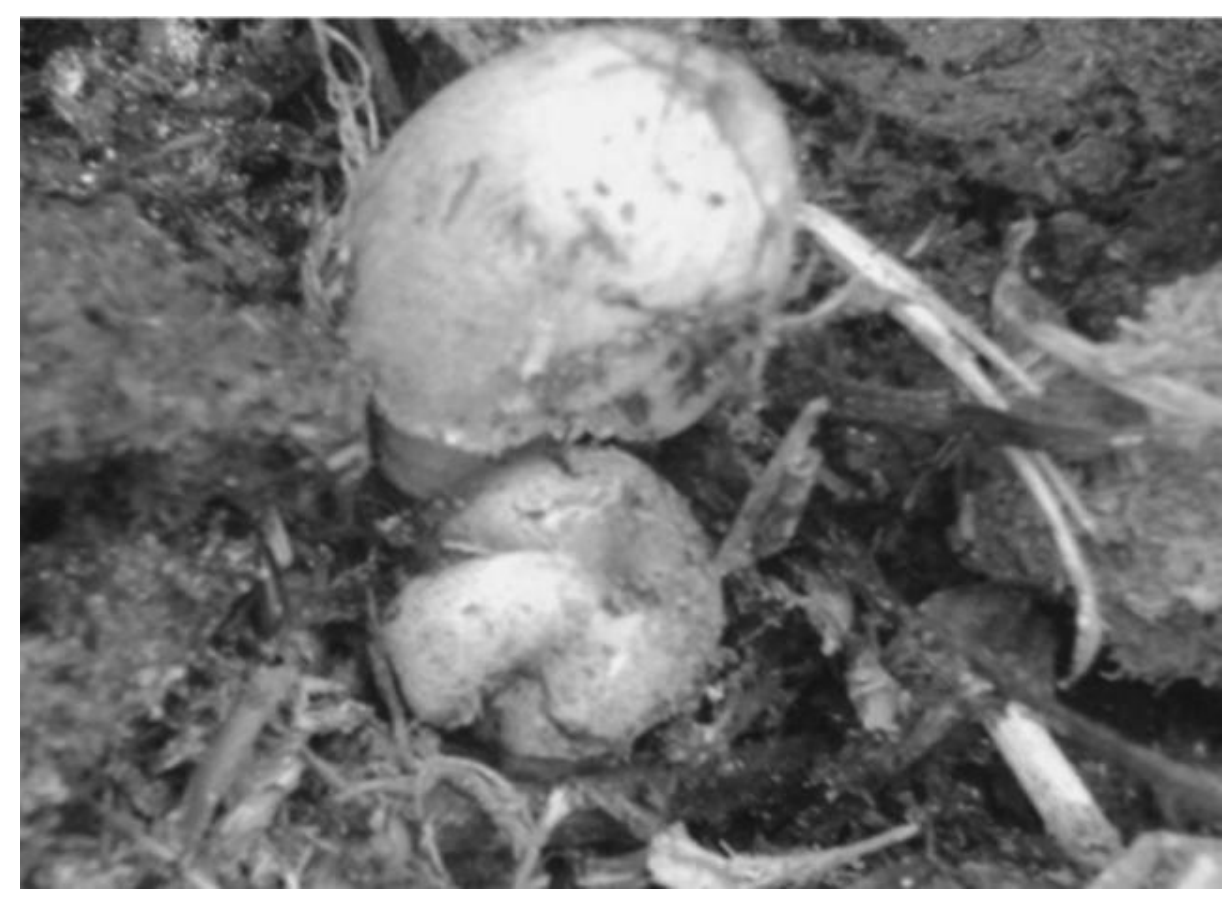

Fig. 12 - Coprinopsis radiata. Carpophores growing in natural habitat.

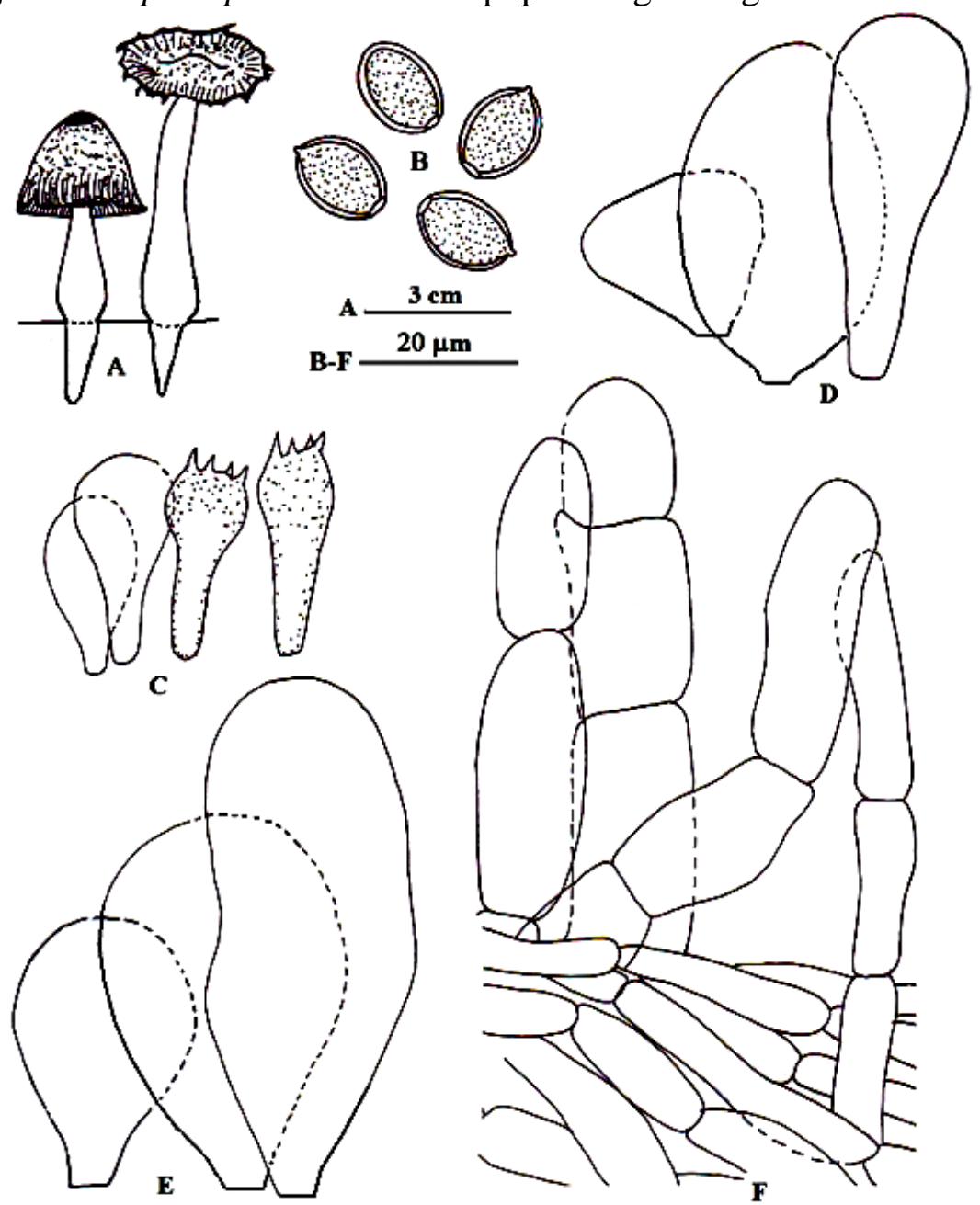

Fig. 13 - Coprinopsis radiata. A Carpophores; B Basidiospores; C Basidia; D Cheilocystidia; E Pleurocystidia; F Pileal elements. 
element tapering upwards; context homoiomerous, made up of interwoven radially oriented, cylindrical to inflated, thin-walled, 5-12 $\mu \mathrm{m}$ broad hyphae. Hymenophoral trama regular composed of thin-walled, hyaline 3.4-10 $\mu \mathrm{m}$ broad hyphae. Subhymenium pseudoparenchymatous. Stipe cuticle hyphal, smooth, context made up of longitudinally tangled, thin-walled, 4.3-13.6 $\mu \mathrm{m}$ broad hyaline hyphae. Clamp connections present in stipe context and veil elements.

Materials examined - India, Punjab, Patiala, Babulpur, alt. $251 \mathrm{~m}$, growing in groups on mixed cattle dung, 08 September 1998, Amanjeet Kaur, PUN 2955; Bhedpura, growing in a caespitose group on mixed cattle dung heap, 16 July 2011, Amandeep Kaur, PUN 4827.

Discussion - The above examined collections are typical of $C$. radiata as described by Uljé \& Noordeloos (1999). It is recognized by its small size and clustered habit. Arora (1986) designated it as 'Miniature Woolly Ink Cap'.

According to Uljé \& Noordeloos (1999), it is a rare but wide-spread coprinoid species in Europe. May \& Wood (1997) reported the species from Australia. Keirle et al. (2004) documented it growing scattered on horse dung from February to July in Hawaiian Islands. Doveri (2010) recorded it growing on horse dung from Italy. In India as well the species is very common. It has been recorded from Kashmir (Abraham 1991), Maharashtra (Patil et al. 1995), Kerala (Bhavani Devi 1995) and Punjab (Rea 1922, Mahju 1933, Atri \& Kaur 2004).

Coprinopsis radiata (Bolton: Fr.) Redhead, Vilgalys and Moncalvo var. macrocarpa Atri, A. Kaur \& M. Kaur var. nov.

Figs. 14-15

MycoBank No. - MB 805964

Etymology - referring to large sized carpophores

Carpophores $10-16 \mathrm{~cm}$ in height. Pileus $1.7-5 \mathrm{~cm}$ broad, $2.1-2.5 \mathrm{~cm}$ high, campanulate to conical; umbonate, umbo short, broad; surface moist, yellowish brown to brown at the disc, elsewhere grayish brown, finally black, deliquescent; pileal veil scaly, scales white, abundant, tightly adhered in young carpophores, scattered at maturity, easily removable; margin irregular, striate up to the apex, radially splitting at maturity; cuticle not peeling; flesh thin, deliquescent, changing to grayish black at maturity or when handled; taste and odor not distinctive. Lamellae free, unequal, crowded, narrow to moderately broad, autolytic, first white, then grayish black to finally black; gill edges smooth. Spore print black. Stipe central, 9.5-15.7 cm long, 0.7-1.1 cm broad, tapering upwards, basal bulb tapering to form a rooting base, hollow, surface white, fibrillose, fibrils easily removable; pseudorrhiza elongated, $3.5-4 \mathrm{~cm}$ long, solid, deeply rooted in dung heap; annulus absent.

Basidiospores (10)11-15.3 × 5.5-8.5 (9.3) $\mu \mathrm{m}(\mathrm{Q}=1.87)$, ellipsoidal, with an apical germ pore, thick-walled, smooth, dark reddish brown to blackish brown. Basidia dimorphic, smaller basidia clavate measuring $12.8-17 \times 7-9.2 \mu \mathrm{m}$ in size, larger basidia elongated cylindrico-clavate measuring 15.6-23 × 7-10 $\mu \mathrm{m}$ in size, 4-spored, thin-walled, hyaline; sterigmata 2-3.6 $\mu \mathrm{m}$ long. Gill edges heteromerous. Cheilocystidia 35.5-48 × 15.5-27 $\mu \mathrm{m}$, ellipsoidal to inflated clavate, thin-walled, hyaline. Pleurocystidia 52.5-74 $\times$ 14-25.5 $\mu \mathrm{m}$, elongated ellipsoidal to inflated clavate, thin-walled, hyaline. Pileus cuticle a cutis supporting filamentous universal veil remnants projecting all over the surface; veil hyphae 45.4-65.4 × 5.7-12.7 $\mu \mathrm{m}$, septate, cylindrical, with uppermost cell tapering, thin-walled, hyaline; context homoiomerous, made up of cylindrical, thin-walled, hyaline 4-14 $\mu \mathrm{m}$ broad hyphae. Hymenophoral trama regular made up of thin-walled hyaline hyphae. Subhymenium pseudoparenchymatous. Stipe context made up of longitudinally intermingled, septate, thin-walled 4.5-18.5 $\mu \mathrm{m}$ broad hyphae. Clamp connections present in stipe context and veil hyphae.

Materials examined - India, Punjab, Sangrur, Bhasaur, alt. $231 \mathrm{~m}$, growing in groups on buffalo dung, 15 September 2007, Amandeep Kaur, PUN 4828 (Holotype); Langrian, growing in groups on mixed cattle dung, 21 June 2008, Amandeep Kaur, PUN 4829; Sandaur, growing scattered on mixed cattle dung, 29 September 2008, Amandeep Kaur, PUN 4831. Patiala, Chhat Bir, alt. $251 \mathrm{~m}$, growing in groups on mixed cattle dung heap, 30 June 2008, Amandeep Kaur, PUN 4830. 


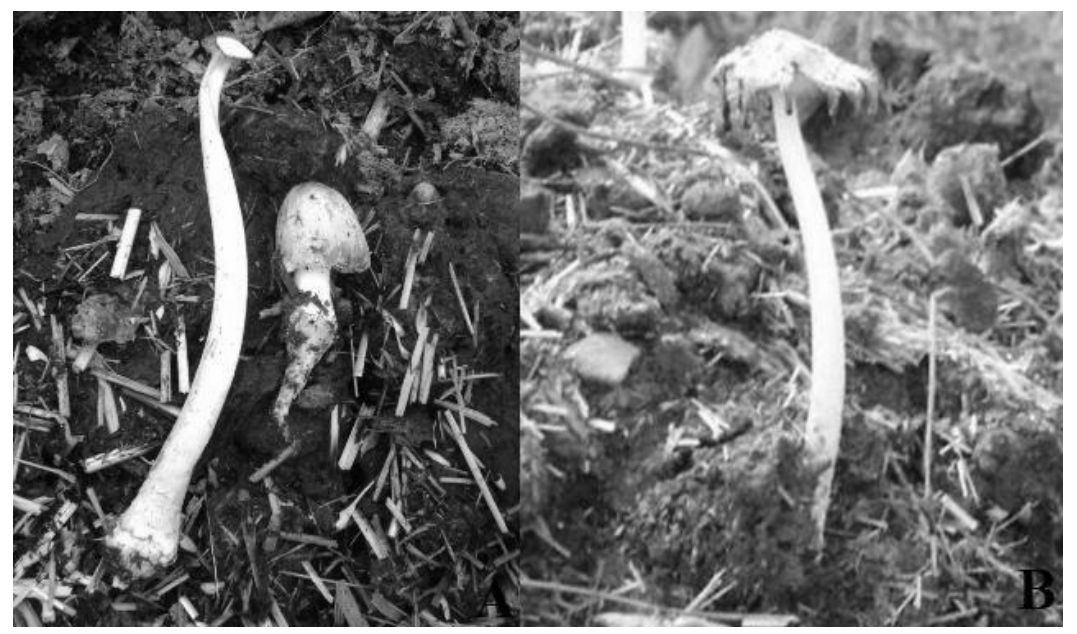

Fig. 14 - Coprinopsis radiata var. macrocarpa. A Young carpophore showing tightly adhered pileal veil and bulbous stipe with a rooting base; B Mature carpophore showing deliquescing pileus.

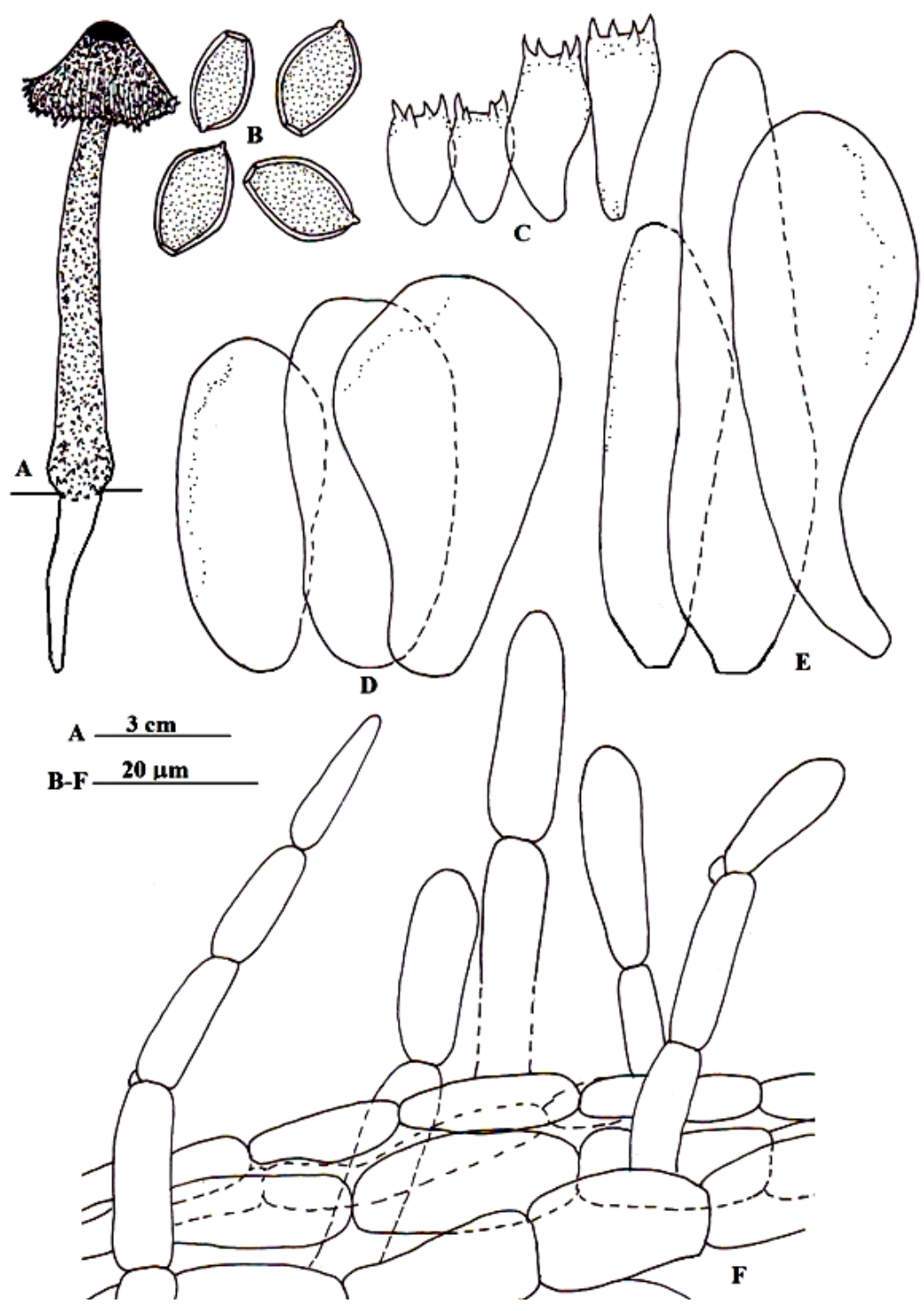

Fig. 15 - Coprinopsis radiata var. macrocarpa. A Carpophore; B Basidiospores; C Basidia; D Cheilocystidia; E Pleurocystidia; F Pileal elements. 
Discussion - The above examined collections are typical of $C$. radiata as described by Uljé \& Noordeloos (1999) except for the carpophore size which is much larger in the presently examined collections. In the Netherland collections the expanded pileus measure up to $1.5 \mathrm{~cm}$ in width and stipe length of the carpophores range from $2-5 \mathrm{~cm}$ as compared to $1.7-5 \mathrm{~cm}$ broad pileus and $9.5-12.7 \mathrm{~cm}$ long stipe documented in the Indian collections. Also the stipe is much broader $(0.7-1.1 \mathrm{~cm})$ as compared to the width of stipe $(0.05-0.2 \mathrm{~cm})$ in the Netherland collections. Beside these characters there is a variation in the velar elements which are reported to be made up of elongated hyphae with sausage shaped cells and cylindrical to almost globose terminal cell in comparison to septate, cylindrical cells arranged in chain like fashion and without any globose termination in the presently examined collections. In view of the above variations in the morphology from $C$. radiata, a new variety $C$. radiata var. macrocarpa has been described.

Coprinopsis foetidella (P. D. Orton) Atri, A. Kaur \& M. Kaur comb. nov.

Figs. $16-17$ Basionym - Coprinus foetidellus P. D. Orton in Notes R. Bot. Gdn. Edinb. 31: 139, 1971.

Carpophores up to $5.5 \mathrm{~cm}$ in height; Pileus up to $1.4 \mathrm{~cm}$ broad, $2.2 \mathrm{~cm}$ high, subglobose to oblong; surface dry, white when young, brownish gray $\left(6 \mathrm{E}_{2}\right)$ at maturity, with brown $\left(6 \mathrm{D}_{5}\right)$ apex; pileal veil abundant, floccose and powdery, covering the entire pileus surface, veil elements removable, surface almost naked after drying; margin irregular, splitting, striated; cuticle fully peeling; flesh thin, white, becoming black when handled; taste not distinctive; odor disagreeable. Lamellae free, unequal, 3-sized, crowded, narrow, up to $0.2 \mathrm{~cm}$ broad, deliquescent, white when young, black at maturity. Spore print black. Stipe central, up to $5.3 \mathrm{~cm}$ long, $0.35 \mathrm{~cm}$ broad, obclavate, tapering upwards, hollow, surface white, unchanging, floccose-fibrillose, fibrils loosely appressed and removable.

Basidiospores 8.6-12.9 × (5) 7.2-9.3 $\mu \mathrm{m}(\mathrm{Q}=1.3)$, ellipsoidal, with a central germ pore, thick-walled, smooth, reddish brown. Basidia dimorphic, smaller basidia ellipsoidal measuring $12-$ $16 \times 9.3-12 \mu \mathrm{m}$, larger basidia pedicellate clavate measuring 20.4-30.6 × 8.5-10 $\mu \mathrm{m}$, all 4-spored, thin-walled, granular; sterigmata 3.4-5 $\mu \mathrm{m}$ long. Pseudoparaphyses present between the basidia. Gill edges heteromerous. Cheilocystidia 42.5-76.5 × 20.4-35.7 $\mu \mathrm{m}$, flattened clavate or balloon shaped, thin-walled, weakly granular to hyaline. Pleurocystidia 56-95 × 24-43 $\mu \mathrm{m}$, inflated clavate, thin-walled, weakly granular to hyaline. Pileus cuticle a cutis of hyphoid elements with appressed cellular veil over the surface; veil elements $35.7-49.3 \times 29-46 \mu \mathrm{m}$, subglobose to globose, thin-walled, warty, warts nipple shaped, do not dissolve in dilute $\mathrm{HCl}$ solution; pileus context homoiomerous, made up of interwoven, cylindrical, thin-walled, 5-12 $\mu \mathrm{m}$ broad hyphae. Hymenophoral trama regular, composed of thin-walled hyaline 5-16 $\mu \mathrm{m}$ broad hyphae. Subhymenium pseudoparenchymatous. Stipe cuticle hyphal, context made up of cylindrical, septate, thin-walled, hyaline 6.8-22 $\mu \mathrm{m}$ broad hyphae. Clamp connections absent throughout.

Material examined - India: Punjab: Moga, Jallalabad, alt. $217 \mathrm{~m}$, growing in a group on buffalo dung, 28 June 2011, Amandeep Kaur (PUN 4818).

Discussion - In the present collection the gross morphological and microscopical details are quite close to $C$. foetidellus except the slightly larger spores measuring 8.6-12.9 x (5)7.2-9.3 $\mu \mathrm{m}$ in size as compared to small sized spores measuring 7.6-10.8 $\mathrm{x}$ 4.6-7 $\mu \mathrm{m}$ (http://www.grzyby.pl/coprinus-site-Kees-Uljee/species/foetidel.htm). The species is recognized by the small sized carpophores, strongly disagreeable smell and the presence of warts on the pileal veil.

It is reported to be a rare species growing on pure or mixed dung from England and the Netherlands (http://www.grzyby.pl/coprinus-site-Kees-Uljee/species/foetidel.htm). Presently the collection was found growing on buffalo dung for the first time from India. Since the external and internal features of the presently examined collection are typical of the genus Coprinopsis in all respects, hence a new combination, Coprinopsis foetidella, has been made to accommodate this collection. 


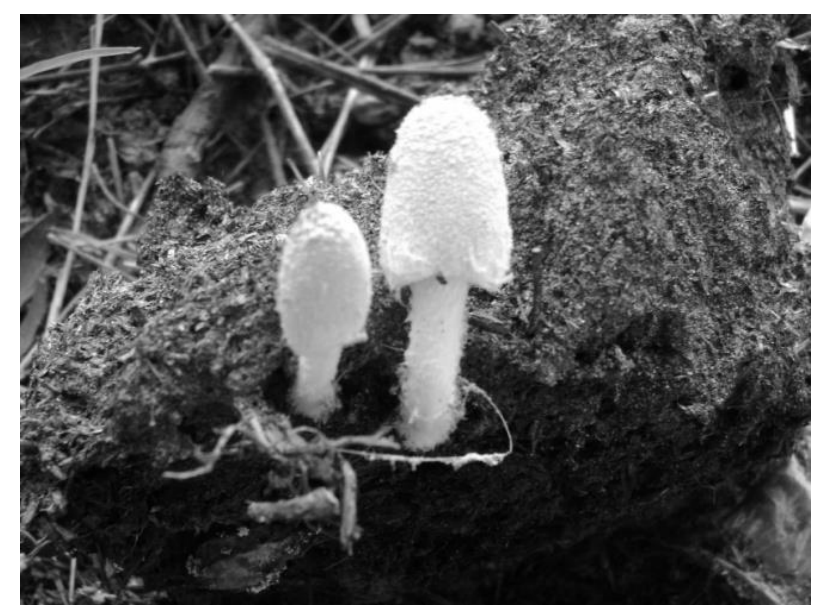

Fig. 16 - Coprinopsis foetidella. Carpophores growing in natural habitat.

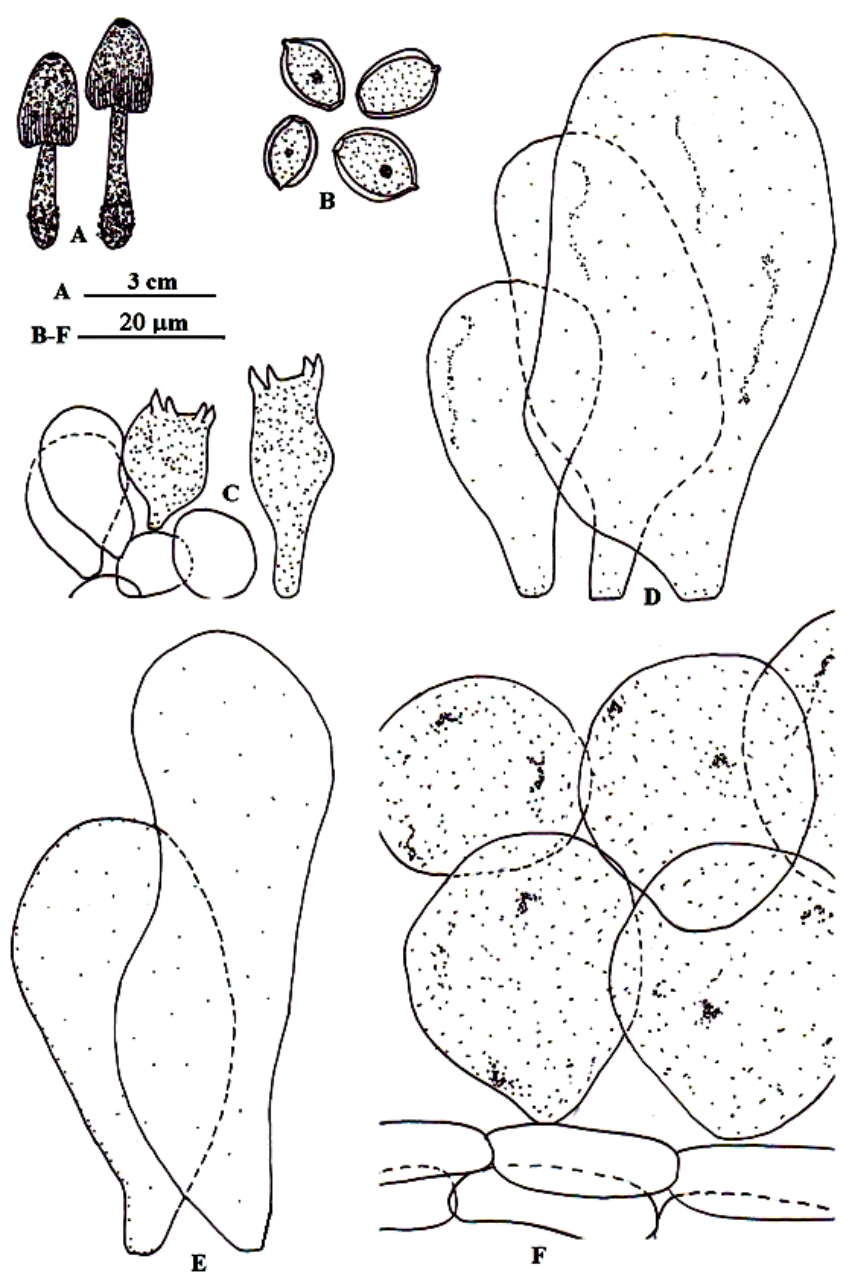

Fig. 17 - Coprinopsis foetidella. A Carpophores; B Basidiospores; C Basidia; D Cheilocystidia; E Pleurocystidia; F Pileal elements.

Coprinopsis cothurnata (Godey) Redhead, Vilgalys and Moncalvo in Taxon 50(1): 227, 2001 var. equsterca Atri, A. Kaur \& M. Kaur var. nov.

Fig. 18 MycoBank No. - MB 805965

Etymology - The name of the variety has been drawn from the scientific name for horse on whose dung the fungus was found growing.

Basionym - Coprinus cothurnatus Godey in Les Hyménomycètes 1: 605, 1874. 
Carpophores $1.5-8.2 \mathrm{~cm}$ in height; Pileus $1.4-1.8 \mathrm{~cm}$ broad, ovoid to conical when young, applanate at maturity; surface moist, grayish white to grayish cream when young, grayish green $\left(27 \mathrm{C}_{5}\right)$ at maturity, with brown $\left(6 \mathrm{E}_{6}\right)$ apex; pileal veil white, floccose to appressed fibrillose, removable, surface glabrous at maturity; margin irregular, striate, plicate-grooved; cuticle half peeling; flesh thin, pale, shriveling, becoming black at maturity; taste and odor not distinctive. Lamellae free, equal, crowded, narrow, white when young, brownish black at maturity. Spore print black. Stipe central, $1.4-8 \mathrm{~cm}$ long, $0.3-0.6 \mathrm{~cm}$ broad, tapering upwards, bulbous at the base, hollow, surface white, becoming yellowish red at the basal portion when handled, pruinose, floccose near the base.

Basidiospores 8.5-13 × 5-8.5 $\mu \mathrm{m}(\mathrm{Q}=1.59)$, subhexagonal in face view, ellipsoidal in side view, with central to rarely eccentric germ pore, thick-walled, smooth, reddish brown. Basidia trimorphic, smaller basidia ellipsoidal measuring 7-11 $\times 6.4-7.8 \mu \mathrm{m}$, medium sized basidia clavate pyriform measuring 11-14.2 $\times 5-7 \mu \mathrm{m}$, larger basidia elongated cylindrical with long pedicellate base measuring 18.5-25.5 $\times 5.7-7 \mu \mathrm{m}$, all 4-spored, thin-walled, granular; sterigmata 2-5 $\mu \mathrm{m}$ long. Gill edges heteromerous. Cheilocystidia 14.2-26 × 11.4-20 $\mu \mathrm{m}$, inflated clavate, thin-walled, hyaline. Pleurocystidia absent. Pileus cuticle a cutis with veil in the form of sphaerocysts; veil cells 32-35 $\mu \mathrm{m}$ broad, thin-walled, with granular crystals that dissolve in dilute $\mathrm{HCl}$; pileus context homoiomerous, made up of cylindrical, thin-walled 2.8-11.4 $\mu \mathrm{m}$ broad hyphae. Hymenophoral trama regular, made up of thin-walled 4.3-7 $\mu \mathrm{m}$ broad hyphae. Subhymenium pseudoparenchymatous. Stipe context hyphae cylindrical, longitudinally intermingled, compact, thin-walled, hyaline, 5.7-21.3 $\mu \mathrm{m}$ broad. Clamp connections not observed.

Material examined - India, Punjab, Barnala, Salempur, alt. 228 m, growing in a caespitose group on horse dung, 08 February 2009, Amandeep Kaur, PUN 4064.

Discussion - The gross external and internal details of the presently worked out collection matches with the details given for $C$. cothurnata by Uljé \& Noordeloos (1993). But the spores are slightly smaller in size measuring $8.5-13 \times 5-8.5 \mu \mathrm{m}$ and pleurocystidia are absent in the above examined collection in comparison to $9.6-15.4 \times 6.5-8.7 \mu \mathrm{m}$ sized spores and sparsely present pleurocystidia as described by Uljé \& Noordeloos (1993). Also clamp connections have not been observed presently whereas Uljé \& Noordeloos (1993) reported the presence of clamp connections in European collections. In view of these differences, a new variety $C$. cothurnata var. equsterca has been proposed to accommodate this collection.

According to Uljé \& Noordeloos (1993), it is a common species found growing solitary to scattered on dung from Europe. Keirle et al. (2004) recorded it growing in pastures on cattle dung during the months of August to October from Hawaiian Islands. Doveri (2010) recorded this species growing on cattle dung from Italy. The present collection was made from horse dung in the month of February.

Coprinopsis nivea (Pers.) Redhead, Vilgalys and Moncalvo in Taxon 50(1): 229, 2001. Figs. 19-20 Basionym - Agaricus niveus Persoon in Synopsis Methodica Fungorum p. 400, 1801.

Synonyms - Coprinus niveus (Persoon) Fries in Epicrisis p. 246, 1838.

Coprinus latisporus P.D. Orton in Notes Roy. Bot. Gard. Edinburgh 32: 140, 1972.

Carpophores 5.4-22 cm in height; Pileus 2-5.4 cm broad, 1.7-2.7 cm high, ellipsoidal to campanulate when young, convex at maturity, finally applanate with reflexed margin; umbonate, umbo broad, brown $\left(6 \mathrm{E}_{6}\right)$; surface dry, pure white when young, mouse grey $\left(5 \mathrm{E}_{3}\right)$ to grayish brown $\left(6 \mathrm{E}_{3}\right)$ at maturity; pileal veil white, powdery and hairy flocculose, completely covering the entire pileus surface in young specimens, scattered in mature carpophores; margin irregular, splitting, striated, folded upward at maturity; cuticle not peeling; flesh membranous, shriveling, pale, blackening towards maturity to slightly deliquescent; taste and odor not distinctive. Lamellae free to adnexed, unequal, 3- to 4-sized, crowded, narrow to moderately broad, $0.2-0.3 \mathrm{~cm}$ broad, white when young, grayish black at maturity; gill edges smooth. Spore print black. Stipe $5.2-21 \mathrm{~cm}$ long, 

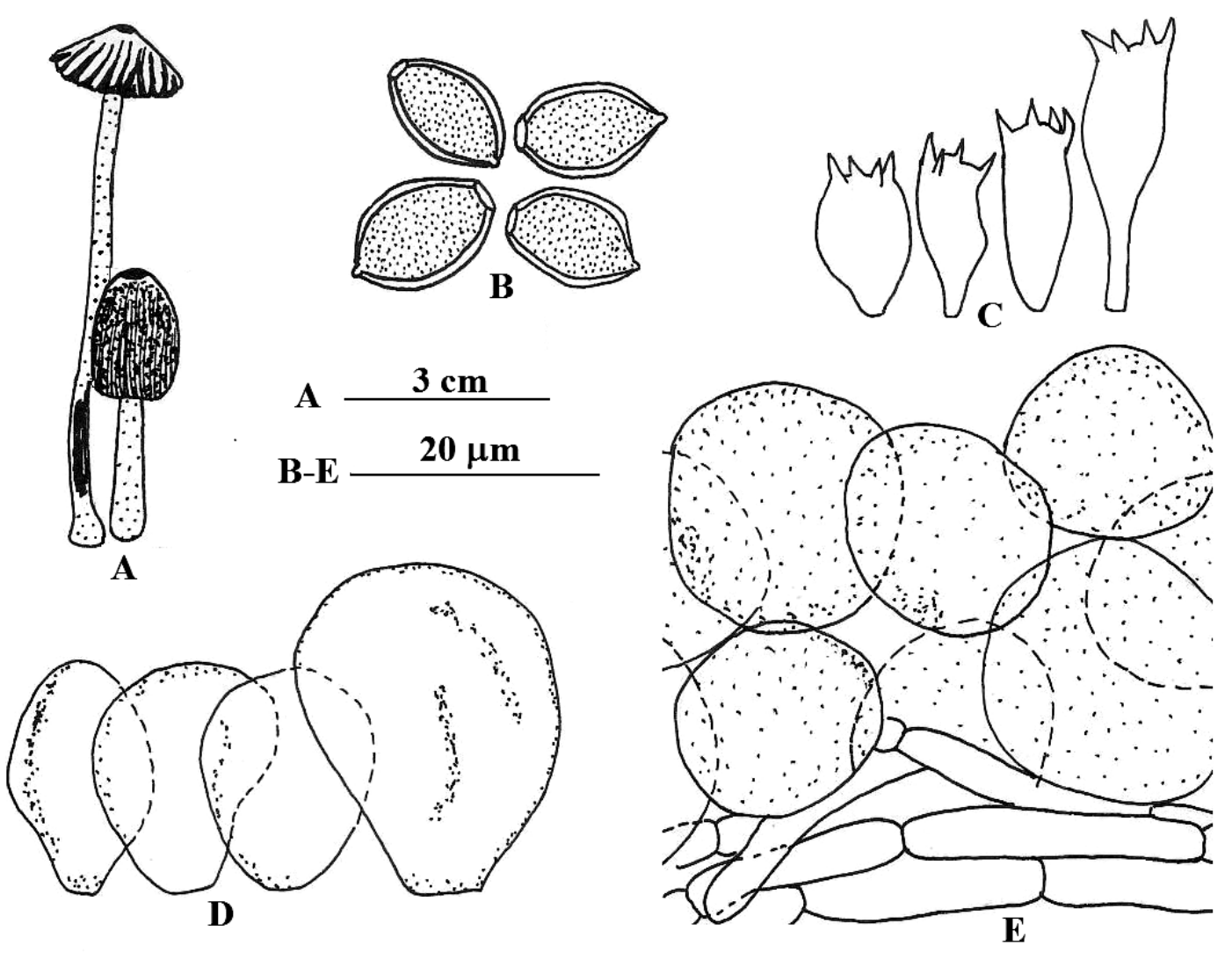

Fig. 18 - Coprinopsis cothurnata var. equsterca. A Carpophores; B Basidiospores; C Basidia; D Cheilocystidia; E Pileal cuticle with overlying veil elements.

0.45-0.9 cm broad, cylindrical, with bulbous base, hollow, surface white, unchanging, pruinosefibrillose.

Basidiospores $12-15.3 \times 8.5-12.7 \mu \mathrm{m}(\mathrm{Q}=1.28)$, lenticular to limoniform-subhexagonal in face view, ellipsoidal in side view, with a central to eccentric germ pore, thick-walled, smooth, dark reddish brown. Basidia 15.3-27 × 5-9.3 $\mu \mathrm{m}, 2-$, 4-spored, thin walled, hyaline. Gill edges heteromerous. Cheilocystidia 29-71 $\times 17-42.4 \mu \mathrm{m}$, ellipsoidal to inflated clavate, thin-walled, weakly granular to hyaline. Pleurocystidia $24-63 \times 15-42.4 \mu \mathrm{m}$, pedicellate clavate to inflated clavate, thin-walled, weakly granular to hyaline. Pileus cuticle a cutis supporting cellular veil; velar elements $17-46 \times 23.8-40 \mu \mathrm{m}$, globose to subglobose, thin walled, crystalline, crystals dissolving in dilute $\mathrm{HCl}$ after some time; pileus context homoiomerous, made up of cylindrical, thin walled, hyaline 4.3-12 $\mu \mathrm{m}$ broad hyphae. Hymenophoral trama composed of subparallel, thin-walled 4.3$10 \mu \mathrm{m}$ broad hyphae. Subhymenium pseudoparenchymatous. Stipe cuticle hyphal, context hyphae almost parallel to each other, compactly arranged, thin-walled, 8.5-24 $\mu \mathrm{m}$ broad. Clamp connections present throughout.

Materials examined - India, Punjab, Sangrur, Amargarh, alt. $231 \mathrm{~m}$, growing in groups on buffalo dung, 21 June 2008, Amandeep Kaur, PUN 4821; Mahorana, growing in caespitose groups on buffalo dung, 21 June 2008, Amandeep Kaur, PUN 4822; Takhar, growing gregariously on buffalo dung, 26 June 2008, Amandeep Kaur, PUN 4823; Chittanwala, alt. $231 \mathrm{~m}$, growing in groups on buffalo dung flakes, 25 July 2010, Amandeep Kaur, PUN 4825. Ludhiana, Nasrali, alt. 254 m, growing in groups on horse dung, 23 July 2009, Amandeep Kaur, PUN 4824.

Discussion - The above examined collections are typical of $C$. nivea (Uljé \& Noordeloos 1993, Doveri 2010). The species is recognized by its large limoniform-subhexagonal basidiospores, ellipsoidal to campanulate white pileus at young stage which is completely covered by granular veil and reflexed pileal margin at maturity. 


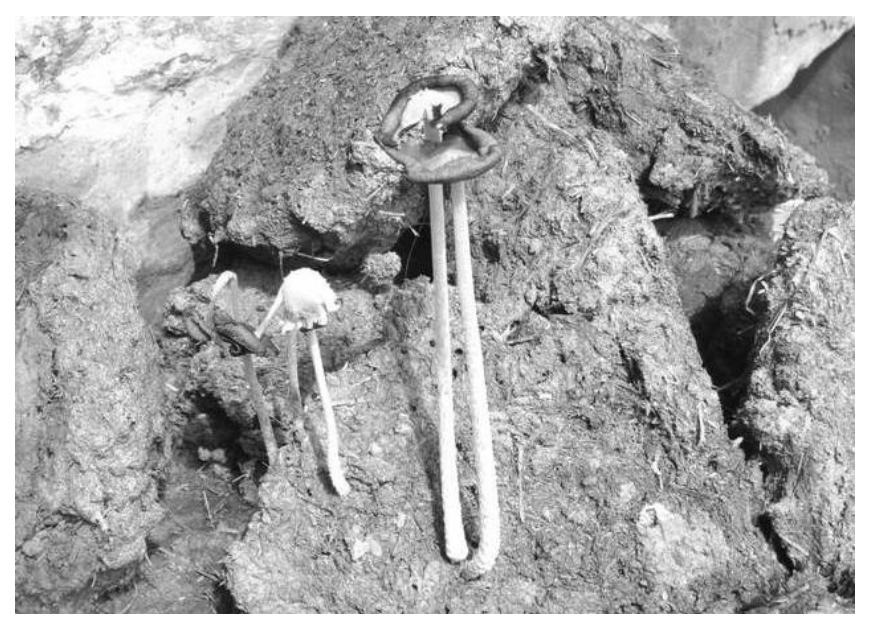

Fig. 19 - Coprinopsis nivea. Carpophores growing in natural habitat.

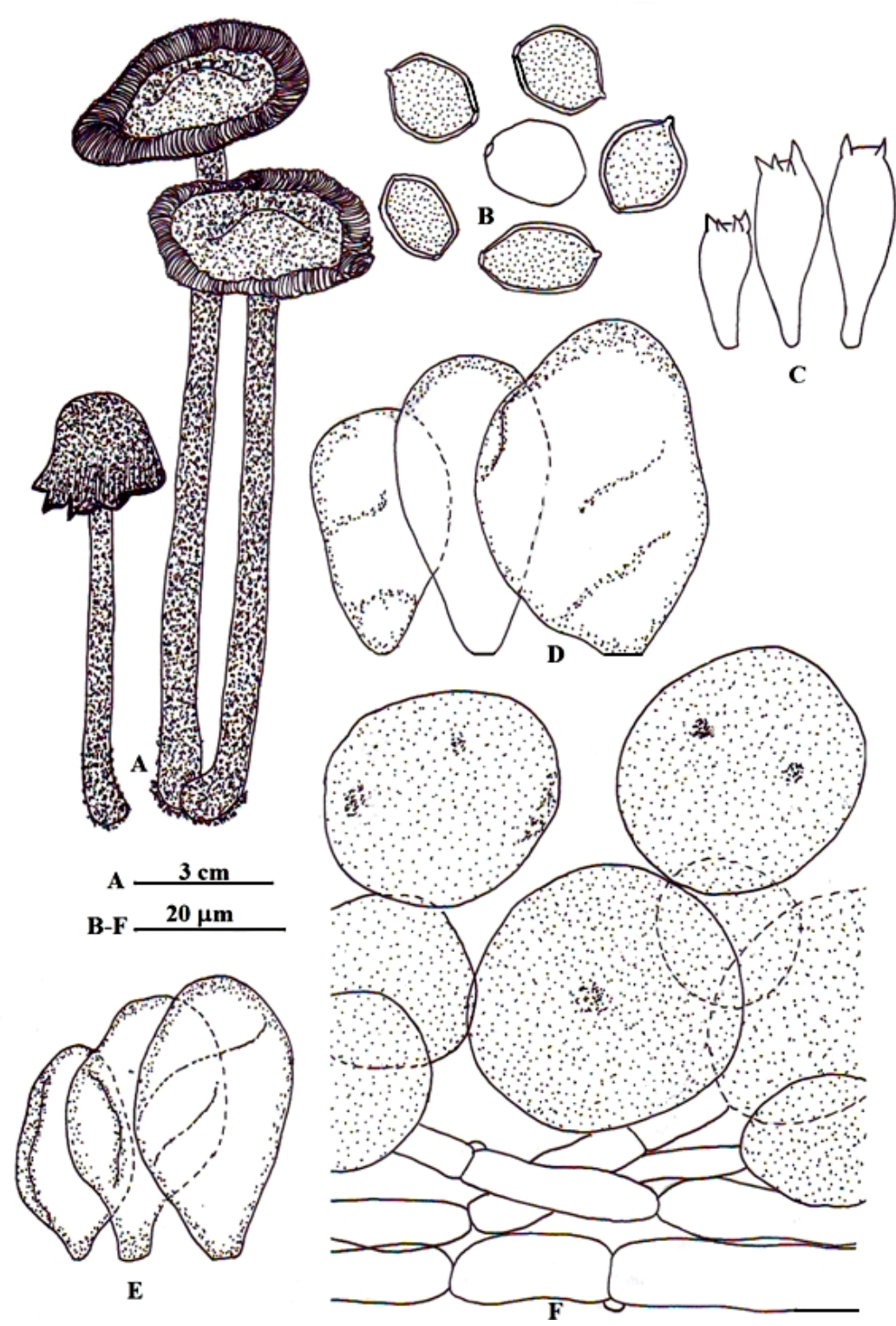

Fig. 20 - Coprinopsis nivea. A Carpophores; B Basidiospores; C Basidia; D Cheilocystidia; E Pleurocystidia; F Pileal elements. 
Uljé \& Noordeloos (1993) documented the species growing solitary to scattered on dung of horse and cow during the months of August to October from the Netherlands and Switzerland. It is also known from Australia (May \& Wood 1997). Doveri (2010) recorded this species growing on cattle dung from Italy. Watling \& Richardson (2010) described $C$. nivea as a common and widespread coprophilous species found on cattle and horse dung from Falkland Islands. Previous records from India are from Punjab (Butler \& Bisby 1931; Mahju 1933), West Bengal (Banerjee 1947), Maharashtra (Patil et al. 1995) and Kerala (Bhavani Devi 1995). In some parts of India it is reported to be edible (Padwick 1941, Purkayastha \& Chandra 1985, Bhavani Devi 1995).

Coprinopsis pseudonivea (Bender and Uljé) Redhead, Vilgalys and Moncalvo in Taxon 50(1): 230, 2001.

Figs. 21-22

Basionym - Coprinus pseudoniveus Bender and Uljé in Persoonia 15(3): 270, 1993.

Carpophores $6.2-15 \mathrm{~cm}$ in height; Pileus $2.8-5.7 \mathrm{~cm}$ broad, $2.4-3.5 \mathrm{~cm}$ high, ellipsoidal to subglobose when young, conico-convex to applanate at maturity; umbonate, umbo broad, brown $\left(6 \mathrm{E}_{4}\right)$; surface dry, light gray $\left(5 \mathrm{C}_{1}\right)$ to grayish brown $\left(6 \mathrm{E}_{3}\right)$, finally mouse grey $\left(5 \mathrm{E}_{3}\right)$; pileal veil granular floccose, white, covering the entire pileus surface, more aggregated along umbo; margin irregular, splitting, striated, reflexed in some carpophores; cuticle not peeling; flesh membranous, shriveling, white, becoming blackish brown at maturity; taste and odor not distinctive. Lamellae free, unequal, 3- to 4-sized, crowded, narrow, $0.2-0.25 \mathrm{~cm}$ broad, first white then grayish black; gill edges smooth. Spore print black. Stipe central, 6-14.8 cm long, 0.4-0.6 cm broad, cylindrical, tapering upwards, sub-bulbous at the base, hollow, surface whitish, unchanging, with dense velar flecks and whitish mycelium at the base in some carpophores.

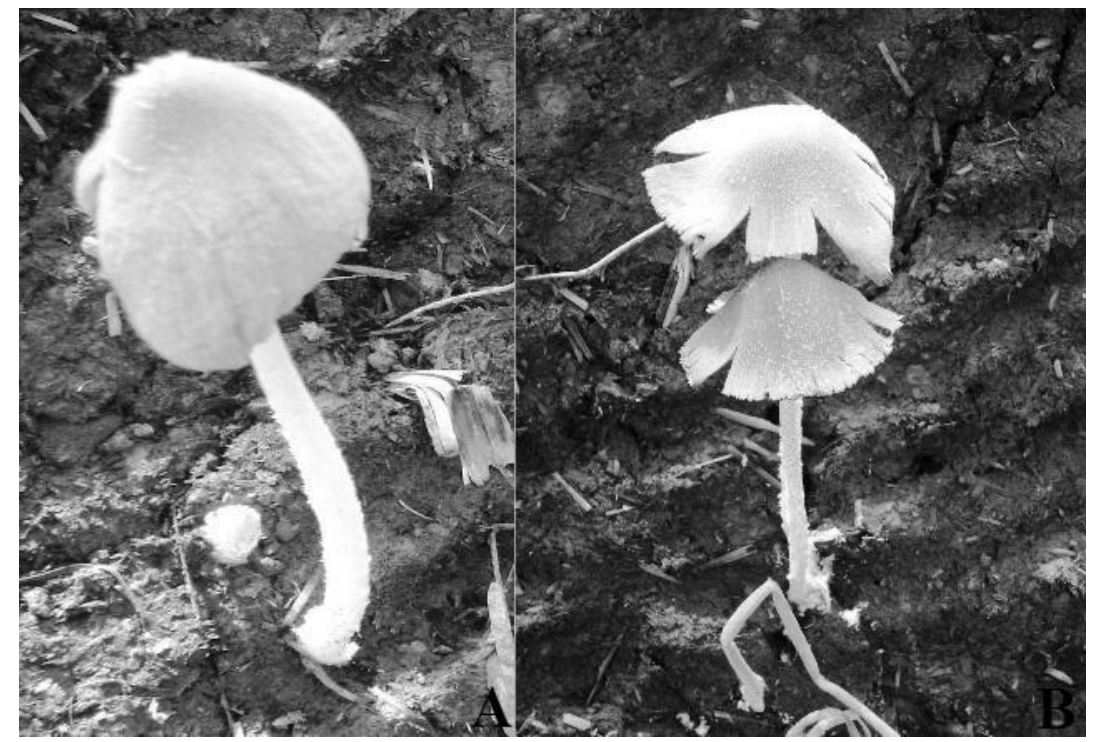

Fig. 21 - Coprinopsis pseudonivea. A Carpophore in young stage showing subglobose pileus; B Mature carpophores showing splitting of pileal margin and densely granular floccose veil.

Basidiospores 9.2-12.8 × 8.5-11 $\mu \mathrm{m}(\mathrm{Q}=1.12)$, lenticular to limoniform-subhexagonal in face view, ellipsoidal in side view, with a central to eccentric germ pore, thick-walled, smooth, reddish brown. Basidia, dimorphic, smaller basidia ellipsoidal to short clavate measuring 8.5-14.2 $\times 6.4-8.5 \mu \mathrm{m}$ in size, larger basidia elongate cylindrico-clavate measuring $15.3-33 \times 5.7-11.5 \mu \mathrm{m}$ in size, 4-spored, thin walled, hyaline; sterigmata $2.8-4.3 \mu \mathrm{m}$ long. Gill edges heteromerous. Cheilocystidia sparse, 28-57 × 14-26 $\mu \mathrm{m}$, vesiculose, subcylindrical to ellipsoidal, thin-walled, hyaline. Pleurocystidia occasional, 25-65 × 11.4-28.4 $\mu \mathrm{m}$, vesiculose, clavate to inflated ellipsoidal, thin-walled, hyaline. Pileus cuticle a cutis with cellular veil; veil elements $21-60 \times 28-$ $54 \mu \mathrm{m}$, subglobose to globose, thin walled, granular, contents dissolve in dilute $\mathrm{HCl}$ solution after 
some time; pileus context homoiomerous, made up of interwoven, thin walled 3-12.7 $\mu \mathrm{m}$ broad hyphae. Hymenophoral trama composed of thin-walled 2.8-8.5 $\mu \mathrm{m}$ broad hyphae. Subhymenium pseudoparenchymatous. Stipe cuticle hyphae lying parallel to each other measuring $4.3-7 \mu \mathrm{m}$ in width, some hyphae projecting, context composed of compactly arranged, intermingled, thinwalled, hyaline 7-28 $\mu \mathrm{m}$ broad hyphae. Clamp connections present in stipe context hyphae.

Materials examined - India, Punjab, Sangrur, Langrian, alt. $231 \mathrm{~m}$, growing in groups on cow dung, 21 June 2008, Amandeep Kaur, PUN 4062; Khurd, growing in groups on mixed cattle dung, 05 July 2008, Amandeep Kaur, PUN 4826. Tarn Taran, Kang, Khadoor Sahib, alt. 169 m, growing in a pair on cow dung, 12 December 2009, Amandeep Kaur, PUN 4063.

Discussion - The above examined collections are typical of $C$. pseudonivea (Uljé \& Noordeloos 1993). It is close to C. nivea from which it differs in having smaller basidiospores and narrower cystidia.

Uljé \& Noordeloos (1993) recorded this species growing solitary to scattered on cow dung and compost heaps from the Netherlands. Doveri (2010) recorded it growing on cattle dung from Italy. In the present study, it has been recorded growing in groups on cow and mixed cattle dung heaps during the months of June, July and December for the first time from India.

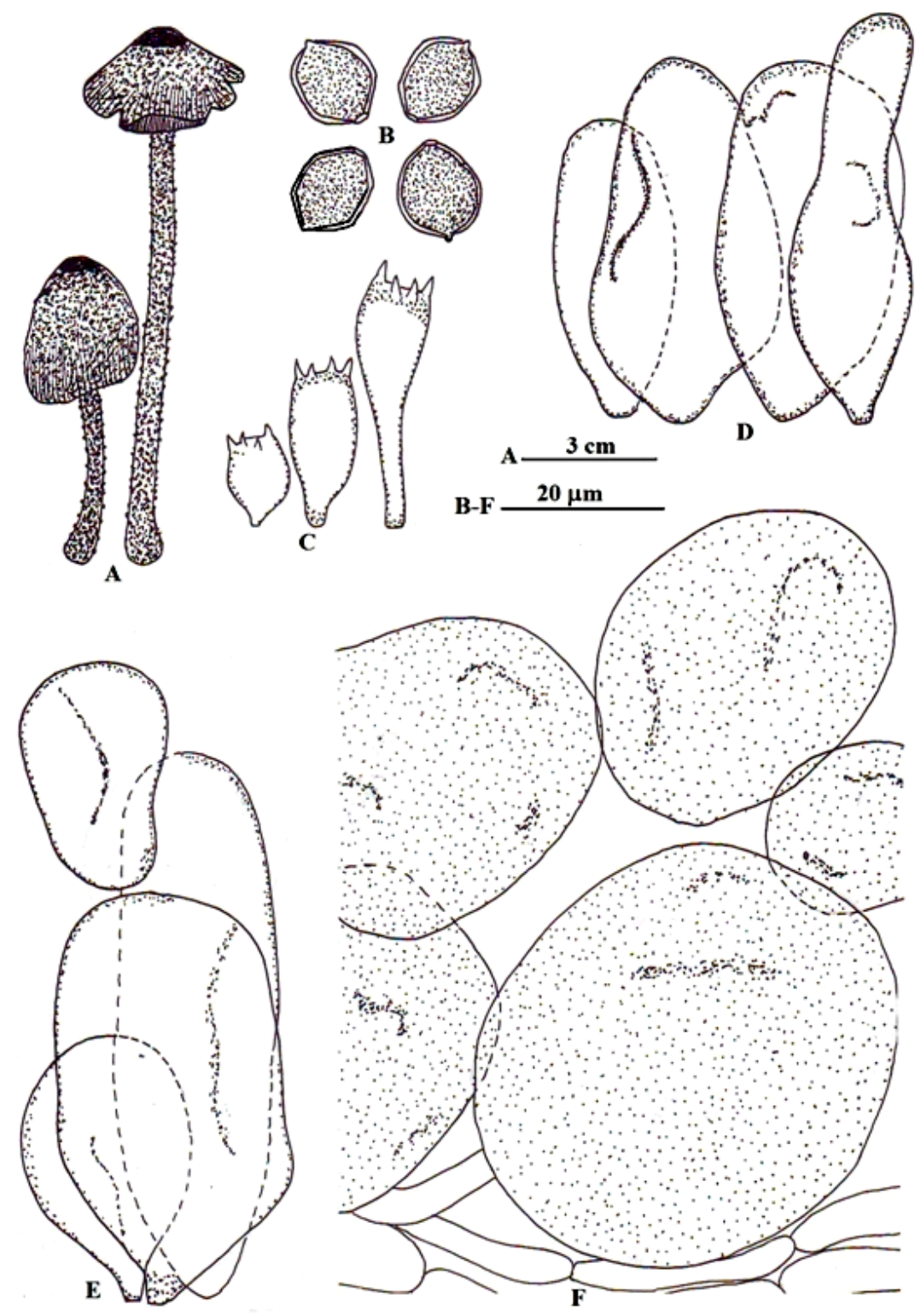

Fig. 22 - Coprinopsis pseudonivea. A Carpophores; B Basidiospores; C Basidia; D Cheilocystidia; E Pleurocystidia; F Pileus cuticle with overlying cellular veil elements. 


\section{Acknowledgements}

Authors wish to thank Department of Botany, Punjabi University, Patiala for providing laboratory facilities and University Grants Commission for financial assistance under SAP-III programme of D.R.S.

\section{References}

Abraham SP 1991 - Kashmir fungal flora - an overview. In: Indian Mushrooms (ed MC Nair). Kerala Agricultural University, Velenikkara, pp 13-24.

Arora D 1986 - Mushrooms Demystified: A Comprehensive Guide to the Fleshy Fungi. Ten Speed Press, Berkeley, California, pp 936.

Atri NS, Kaur A. 2004 - Mushroom flora of Patiala- The genus Coprinus Pers. ex Gray. In: Plant Diversity in India (eds JS Dargan, TA Sarma). Bishen Singh Mahendra pal Singh, Dehra Dun, India, pp 427-448.

Atri NS, Saini SS. 2000 - Collection and study of agarics- an introduction. Indian Journal of Mushrooms 18, 1-5.

Atri NS, Kaur A, Kour H. 2005 - Wild mushrooms- collection and identification. In: Frontiers in Mushroom Biotechnology (eds RD Rai, RC Upadhyay, SR Sharma). National Research Center for Mushroom, Chambaghat, Solan, India, pp 9-26.

Banerjee SN 1947 - Fungal flora of Calcutta and suburbs I. Bulletin of the Botanical Society of Bengal 1, 37-54.

Bhavani Devi S 1995 - Mushroom flora of Kerala. In: Advances in Hortriculture, Vol. 13Mushrooms (eds KL Chadha, SR Sharma). Malhotra Publishing House, New Delhi, pp 277-316.

Butler EJ, Bisby GR. 1931 - The Fungi of India. Science Monograph 1. Indian Council of Agricultural Research India, Calcutta, pp 237.

Crosier WF, Patrick SR, Heit CE, McSwain E. 1949 - The Harefoot Mushroom, Coprinus lagopus Fr., on fruits used commercially as seed stocks. Science 110(2844), 13-14.

Doveri F 2010 - Occurrence of coprophilous Agaricales in Italy, new records, and comparisons with their European and extraeuropean distribution. Mycosphere 1(2), 103-140.

Ginai MA 1936 - Further contribution to knowledge of Indian coprophilous fungi. Journal of the Indian Botanical Society 15, 269-284.

Holmgren PK, Keuken W. 1974 - Index Herbariorum, Part I. Regnum Vegetabile 92, 1-397.

Kaul TN, Kachroo JL. 1974 - Common edible mushrooms of Jammu and Kashmir. Journal of the Bombay Natural History Society 71, 26-31.

Keirle MR, Hemmes DE, Desjardin DE. 2004 - Agaricales of the Hawaiian Islands- 8. Agaricaceae: Coprinus and Podaxis; Psathyrellaceae: Coprinopsis, Coprinellus and Parasola. Fungal Diversity 15, 33-124.

Kirk PF, Cannon PF, Minter DW, Stalpers JA. 2008 - Dictionary of Fungi, 10th ed, CABI Bioscience, CAB International, Wallingford.

Kornerup A, Wanscher JH. 1978 - Methuen Handbook of Colour, 3rd ed, Eyre Methuen, London.

Krishnamurthy V, Verma JP. 1974- Preliminary studies on Boll rot of cotton in India. Cotton Growing Review 51, 26-227.

Mahju NA 1933 - A Contribution to our knowledge of Indian coprophilous fungi. Journal of the Indian Botanical Society 12, 153-164.

Manjula B 1983 - A revised list of Agaricoid and Boletoid Basidiomycetes from India and Nepal. Proceedings of the Indian Academy of Sciences Plant Science 92, 81-213.

May TW, Wood AE. 1997 - Fungi of Australia. Vol 2 A. Catalogue and Bibliography of Australian Macrofungi I: Basidiomycota. Canberra CSIRO Publishing, Australian Biological Resources Studies, Australia, pp 358.

Natarajan K, Raaman N. 1983 - South Indian Agaricales. Bibliotheca Mycologica 89, 1-203. 
Natarajan K, Raaman N. 1984 - South Indian Agaricales. A preliminary study on some dark spored species. International Books and Periodicals Supply Services, New Delhi.

Orton PD 1957 - Notes on British agarics 1-5 (observations on the genus Coprinus). Transactions of the British Mycological Society 40 (2), 263-276.

Orton PD, Watling R. 1979 - British Fungus Flora- Agaric and Boleti 2. Coprinaceae Part1: Coprinus. HMSO, Edinburgh.

Padwick GW 1941 - Mushroom cultivation in India. Indian Farming 11, 363-366.

Pathak NC, Ghosh RN. 1962 - Fungi of Uttar Pradesh. Bulletin of the National Botanic Gardens, No. 62, National Botanic Gardens, Lucknow, India.

Patil BD, Jadhav SW, Sathe AV. 1995 - Mushroom flora of Maharashtra. In: Advances in Hortriculture Vol. 13- Mushrooms (eds KL Chadha, SR Sharma). Malhotra Publishing House, New Delhi, pp 317-228.

Pegler DN 1977 - A Preliminary Agaric flora of East Africa. Kew Bulletin 6, 1-615.

Pegler DN 1986 - Agaric flora of Sri Lanka. Kew Bulletin 12, 1-514.

Pegler DN, Spooner BM, Lewis Smith RI. 1980 - Higher fungi of Antarctica, the subantarctic zone and Falkland Islands. Kew Bulletin 35, 499-562.

Purkayastha RP, Chandra A. 1985 - Manual of Indian Edible Mushrooms. Jagmander Book Agency, New Delhi.

Rea C 1922 - British Basidiomycetaceae: A Handbook to the Larger British Fungi. Cambridge University Press, Cambridge, England, pp 799.

Redhead SA, Vilgalys R, Moncalvo JM, Johnson J, Hopple JS. 2001 - Coprinus Pers. and the disposition of Coprinus species sensu lato. Taxon 50, 203-241.

Saini SS, Atri NS. 1995 - Mushroom flora of Punjab. In: Advances in Hortriculture Vol. 13Mushrooms (eds KL Chadha, SR Sharma). Malhotra Publishing House, New Delhi, pp 375-386.

Türkoğlu A, Kaşik G, Öztürk C, Doğan Hüseyin H. 2007 - New Records for the Macrofungi of Turkey. Turkish Journal of Botany 31, 471-475.

Uljé CB, Noordeloos ME. 1993 - Studies in Coprinus III. Persoonia 15, 257-301.

Uljé CB, Noordeloos ME. 1997 - Studies in Coprinus IV. Persoonia 16, 265-333.

Uljé CB, Noordeloos ME. 1999 - Studies in Coprinus V. Persoonia 17, 165-199.

Van de Bogart F 1979 - The sections of Coprinus present in Western United States. Mycotaxon 9(1), 348-357.

Vasudeva RS 1962- The Fungi of India. Supplement 1, ICAR, New Delhi, pp 206.

Watling R, Gregory NM, 1980 - Larger fungi from Kashmir. Nova Hedwigia 32, 493-564.

Watling R, Richardson MJ, 2010 - Coprophilous fungi of the Falkland Islands. Edinburgh Journal of Botany 67 (3), 399-423. 